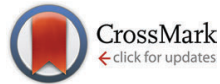

Cite this: New J. Chem., 2015, 39, 7656

Received (in Montpellier, France) 21st April 2015,

Accepted 3rd June 2015

DOI: 10.1039/c5nj00991j

www.rsc.org/njc

\section{One ligand fits all: lanthanide and actinide sandwich complexes comprising the 1,4-bis(trimethylsilyl)cyclooctatetraenyl (=COT ${ }^{\prime \prime}$ ) ligand + \%}

\author{
Janek Rausch, ${ }^{a}$ Christos Apostolidis, ${ }^{\text {b }}$ Olaf Walter, ${ }^{b}$ Volker Lorenz, ${ }^{a}$ Cristian G. Hrib, \\ Liane Hilfert, ${ }^{a}$ Marcel Kühling, ${ }^{a}$ Sabine Busse ${ }^{a}$ and Frank T. Edelmann*a
}

\begin{abstract}
The series of anionic lanthanide(II) sandwich complexes of the type $\left[\mathrm{Ln}\left(\mathrm{COT}^{\prime \prime}\right)_{2}\right]^{-}\left(\mathrm{COT}^{\prime \prime}=1,4\right.$-bis(trimethylsilyl)cyclooctatetraenyl dianion) has been largely extended by the synthesis of eight new derivatives ranging from lanthanum to lutetium. The new compounds [Li(DME) $)_{3}\left[\operatorname{Ln}\left(\mathrm{COT}^{\prime \prime}\right)_{2}\right](\operatorname{Ln}=\mathrm{Y}(\mathbf{1}), \operatorname{La}(\mathbf{2}), \operatorname{Pr}(\mathbf{3}), \mathrm{Gd}(\mathbf{4})$, $\operatorname{Tm}(6), \mathrm{Lu}(\mathbf{8}))$ and $\left[\mathrm{Li}(\mathrm{THF})_{4}\right]\left[\mathrm{Ln}\left(\mathrm{COT}^{\prime \prime}\right)_{2}\right](\mathrm{Ln}=\mathrm{Ho}$ (5), $\mathrm{Tm}(\mathbf{7}))$ were prepared in good yields following a straightforward synthetic protocol which involves the treatment of $\mathrm{LnCl}_{3}$ with 2 equiv. of in situprepared $\mathrm{Li}_{2} \mathrm{COT}^{\prime \prime}$ in either DME (=1,2-dimethoxyethane) or THF. The neutral actinide sandwich complexes $\mathrm{An}\left(\mathrm{COT}^{\prime \prime}\right)_{2}(\mathrm{An}=\mathrm{Th}(\mathbf{9}), \mathrm{U}(\mathbf{1 0}))$ and $\mathrm{An}\left(\mathrm{COT}^{\prime \prime \prime}\right)_{2}\left(\mathrm{COT}^{\prime \prime \prime}=1,3,6\right.$-tris(trimethylsilyl)cyclooctatetraenyl dianion; $\mathrm{An}=\mathrm{Th}$ (11), $\cup(\mathbf{1 2})$ ) were synthesized in a similar manner, starting from $\mathrm{ThCl}_{4}$ or $\mathrm{UCl}_{4}$, respectively. The COT" ligand imparts excellent solubility even in low-polar solvents as well as excellent crystallinity to all new compounds studied. All twelve new f-element sandwich complexes have been structurally authenticated by single-crystal X-ray diffraction. All are nearly perfect sandwich complexes with little deviation from the coplanar arrangement of the substituted COT" rings. Surprisingly, all six $\left[\mathrm{Li}(\mathrm{DME})_{3}\right]\left[\mathrm{Ln}\left(\mathrm{COT}^{\prime \prime}\right)_{2}\right]$ complexes covering the entire range of $\mathrm{Ln}^{3+}$ ionic radii from $\mathrm{La}^{3+}$ to $\mathrm{Lu}^{3+}$ are isostructural (space group $P \overline{1}$ ). Compound $\mathbf{1 0}$ is the first uranocene derivative for which ${ }^{13} \mathrm{C}$ NMR data are reported.
\end{abstract}

\section{Introduction}

Second only to the omnipresent cyclopentadienyl complexes, the dianionic $10 \pi$-cyclooctatetraenyl ligand $\mathrm{C}_{8} \mathrm{H}_{8}{ }^{2-}$, commonly abbreviated as COT, plays an important role in the organometallic chemistry of lanthanides and actinides for almost 50 years. There is a general understanding that the large, flat $\mathrm{C}_{8} \mathrm{H}_{8}{ }^{2-}$ ring is ideally suited for overlapping with the f-orbitals of the large lanthanide and actinide ions. ${ }^{1}$ Early work in this area was mainly focused on complexes bearing unsubstituted COT ligands. ${ }^{2}$ Scheme 1 shows some prototypical lanthanide COT complexes which are considered milestones in the development of organolanthanide chemistry using COT ligands.

\footnotetext{
${ }^{a}$ Chemisches Institut der Otto-von-Guericke-Universität Magdeburg,

Universitätsplatz 2, 39106 Magdeburg, Germany.

E-mail: frank.edelmann@ovgu.de; Fax:+49 391 6712933; Tel: +49 3916758327

${ }^{b}$ European Commission, Joint Research Centre, Institute for Transuranium

Elements, P.O. Box 2340, 76125 Karlsruhe, Germany.

E-mail: christos.apostolidis@ec.europa.eu

$\dagger$ Dedicated to Professor Basil Kanellakopulos on the occasion of his 80th birthday.

\# CCDC 1052366-1052372 (1-8) and 1049924-1049927 (9-12). For crystallographic data in CIF or other electronic format see DOI: 10.1039/c5nj00991j
}

Notable are the anionic sandwich complexes $\mathrm{K}\left[\operatorname{Ln}(\mathrm{COT})_{2}\right]$ $(\mathbf{A}){ }^{3}$ the dimeric half-sandwich mono(cyclooctatetraenyl)lanthanide chlorides $\left[(\mathrm{COT}) \operatorname{Ln}(\mu-\mathrm{Cl})(\mathrm{THF})_{2}\right]_{2}$ (B), ${ }^{4}$ the mixedsandwich complexes (COT)LnCp (C), ${ }^{5}$ and the so-called cerocene, $\mathrm{Ce}(\mathrm{COT})_{2}$ (D). ${ }^{6}$ The chemistry of such lanthanide COT complexes has already been summarized in several comprehensive review articles. ${ }^{2,7}$

In the case of actinides, the discovery of uranocene, $\mathrm{U}(\mathrm{COT})_{2}$ (Scheme 2, An = U), by Streitwieser and Müller-Westerhoff in 1968 had a considerable impact on the development of organoactinide chemistry. ${ }^{11,12}$ Following the preparation of uranocene, other tetravalent actinidocenes $\mathrm{An}\left(\mathrm{C}_{8} \mathrm{H}_{8}\right)_{2}$ (Scheme 2; An = Th, Pa, $\mathrm{Np}, \mathrm{Pu}$ ) have also been reported. ${ }^{12}$ The bonding in uranocene is considered to be less ionic than in the lanthanide sandwich complexes $\mathrm{K}\left[\mathrm{Ln}(\mathrm{COT})_{2}\right](\mathbf{A})$ and $\mathrm{Ce}(\mathrm{COT})_{2}(\mathbf{D})$. Uranocene is also significantly more stable than cerocene and the thorium analogue $\mathrm{Th}(\mathrm{COT})_{2}$, which can be explained by a higher degree of covalency due to a stronger participation of the $5 \mathrm{f}$ and $6 \mathrm{~d}$ orbitals in the uranium-cyclooctatetraenyl bonding. Recent work by Ephritikhine and co-workers has demonstrated that the chemistry of actinidocenes continues to produce very interesting results. ${ }^{13}$

In general, the use of the unsubstituted COT ligand in organolanthanide and -actinide chemistry has several disadvantages 


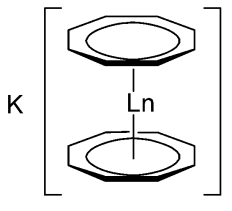

A

Streitwieser et al. $(1970)^{3}$

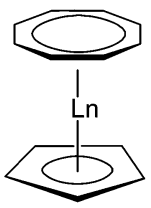

C

Takats et al. $(1974)^{5}$

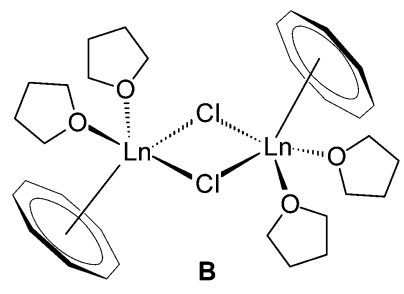

Streitwieser et al. (1971) ${ }^{4}$

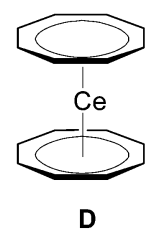

Greco et al. (1976)
Scheme 1 Prototypical lanthanide COT sandwich and half-sandwich complexes.

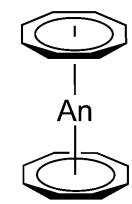

$\mathrm{An}=\mathrm{Th}, \mathrm{Pa}, \mathrm{U}, \mathrm{Np}, \mathrm{Pu}$

Scheme 2 Schematic representation of the neutral actinidocenes $\mathrm{An}\left(\mathrm{C}_{8} \mathrm{H}_{8}\right)_{2}(\mathrm{An}=\mathrm{Th}, \mathrm{Pa}, \mathrm{U}, \mathrm{Np}, \mathrm{Pu})$.

in terms of low solubility and/or poor crystallinity. For example, the most important series of precursors in lanthanide COT chemistry, the chloro-bridged mono(COT) dimers [(COT)Ln$\left.(\mu-\mathrm{Cl})(\mathrm{THF})_{2}\right]_{2}$ (Scheme $\left.1, \mathbf{B}\right),{ }^{4}$ lack good solubility even in THF. Moreover, commercially available cyclooctatetraene is very expensive. As a consequence, more soluble alternative starting materials such as (COT) $\operatorname{LnI}(\mathrm{THF})_{n}(\mathrm{Ln}=\mathrm{Tm}, n=2 ; \mathrm{Ln}=\mathrm{La}$, Ce, $\mathrm{Pr}, \mathrm{Nd}, \mathrm{Sm}, n=3)^{2,8}$ and $\left[(\mathrm{COT}) \operatorname{Ln}\left(\mu-\mathrm{O}_{3} \mathrm{SCF}_{3}\right)(\mathrm{THF})\right]_{2}(\mathrm{Ln}=\mathrm{Ce}$, $\mathrm{Pr}, \mathrm{Nd}, \mathrm{Sm})^{9}$ have been reported in the literature, but their use as precursors in organolanthanide chemistry still remains limited. $^{2}$ More recently, lanthanide COT chemistry received fundamental new impulses through the use of bulky silylsubstituted cyclooctatetraenyl ligands. The initial idea originated from the pioneering work of Cloke et al., who first employed the 1,4-bis(trimethylsilyl)cyclooctatetraenyl dianion $\left(=\mathrm{COT}^{\prime \prime}\right)$ in organo-f-element chemistry. ${ }^{10}$ In many cases, using the bulky COT $^{\prime \prime}$ ligand did in fact improve the solubility of the products, but occasionally also led to novel molecular structures and coordination geometries. ${ }^{7 g, 10,14}$ Typical examples include the unprecedented cluster-centered $\mathrm{Pr} / \mathrm{Li}$ multidecker sandwich complex of the composition $\left[\operatorname{Pr}\left(\mathrm{COT}^{\prime \prime}\right)\right]_{2}\left[\operatorname{Pr}_{2}\left(\mathrm{COT}^{\prime \prime}\right)_{2}\right]_{2} \mathrm{Li}_{2}(\mathrm{THF})_{2} \mathrm{Cl}_{8}{ }^{15}$ as well as the first linear rare-earth metal triple-decker complexes $\mathrm{Ln}_{2}\left(\mathrm{COT}^{\prime \prime}\right)_{3}(\mathrm{Ln}=\mathrm{Nd}, \mathrm{Gd}, \mathrm{Dy}, \mathrm{Ho}, \mathrm{Er}) .{ }^{14,16-18}$ Previously reported anionic lanthanide sandwich complexes comprising $\left[\mathrm{Ln}\left(\mathrm{COT}^{\prime \prime}\right)_{2}\right]^{-}$ anions include the THF solvates $\left[\mathrm{Li}(\mathrm{THF})_{4}\right]\left[\operatorname{Ln}\left(\mathrm{COT}^{\prime \prime}\right)_{2}\right]$ with
$\mathrm{Ln}=\mathrm{Y},{ }^{19} \mathrm{Ce},{ }^{19} \mathrm{Pr},{ }^{19} \mathrm{Nd},{ }^{14,19} \mathrm{Sm},{ }^{19} \mathrm{Gd}^{17}$ and $\mathrm{Dy}^{17}$ as well as the DME adducts $\left[\mathrm{Li}(\mathrm{DME})_{3}\right]\left[\operatorname{Ln}\left(\mathrm{COT}^{\prime \prime}\right)_{2}\right]\left(\mathrm{Ln}=\mathrm{Ce},{ }^{14,20} \mathrm{Dy},{ }^{17}\right.$ $\left.\mathrm{Er}^{21}\right), \operatorname{Li}(\mathrm{DME}) \mathrm{Tb}\left(\mathrm{COT}^{\prime \prime}\right)_{2}{ }^{22}$ and $\mathrm{Li}(\mathrm{THF})(\mathrm{DME}) \mathrm{Dy}\left(\mathrm{COT}^{\prime \prime}\right)_{2} \cdot{ }^{23} \mathrm{~A}$ notable neutral lanthanide sandwich complex containing $\mathrm{COT}^{\prime \prime}$ is the cerocene derivative $\mathrm{Ce}\left(\mathrm{COT}^{\prime \prime}\right)_{2} \cdot{ }^{24}$ Sterically even more demanding is the 1,3,6-tris(trimethylsilyl)cyclooctatetraenyl dianion ligand (=COT $\left.{ }^{\prime \prime \prime}\right)$, which has also been successfully employed in organolanthanide $^{24-26}$ and -actinide chemistry. ${ }^{24,27}$

Recent findings by Murugesu and co-workers revealed that some of the anionic $\left[\operatorname{Ln}\left(\mathrm{COT}^{\prime \prime}\right)_{2}\right]^{-}$sandwich complexes behave as organometallic single-molecule magnets. ${ }^{17,20,21,23}$ Due to the renewed interest in this class of compounds, we carried out a broader investigation on lanthanide and actinide COT $^{\prime \prime}$ sandwich complexes. In this contribution we report the synthesis and structural characterization of the new anionic lanthanide sandwich complexes $\left[\operatorname{Li}(\mathrm{DME})_{3}\right]\left[\operatorname{Ln}\left(\mathrm{COT}^{\prime \prime}\right)_{2}\right](\mathrm{Ln}=\mathrm{Y}(\mathbf{1}), \mathrm{La}(\mathbf{2})$, Gd (4), Tm (6), Lu (8)) and $\left[\mathrm{Li}(\mathrm{THF})_{4}\right]\left[\mathrm{Ln}\left(\mathrm{COT}^{\prime \prime}\right)_{2}\right](\mathrm{Ln}=\operatorname{Pr}(3)$, Ho (5), Tm (7)) as well as the neutral actinide sandwich complexes $\operatorname{An}\left(\mathrm{COT}^{\prime \prime}\right)_{2}(\mathrm{An}=\mathrm{Th}(\mathbf{9}), \mathrm{U}(\mathbf{1 0}))$ and $\mathrm{An}\left(\mathrm{COT}^{\prime \prime \prime}\right)_{2}(\mathrm{An}=\mathrm{Th}(\mathbf{1 1})$, $\mathrm{U}$ (12)). Most recently, after this work had been completed, Murugesu et al. reported the synthesis, structure, and magnetic properties of the closely related uranium(III) sandwich complex $\left[\mathrm{Li}(\mathrm{DME})_{3}\right]\left[\mathrm{U}\left(\mathrm{COT}^{\prime \prime}\right)_{2}\right]$ and the isostructural and isoelectronic lanthanide analogue $\left[\mathrm{Li}(\mathrm{DME})_{3}\right]\left[\mathrm{Nd}\left(\mathrm{COT}^{\prime \prime}\right)_{2}\right]$. This work also included the synthesis and structural characterization of the neutral uranocene derivative $\mathrm{U}\left(\mathrm{COT}^{\prime \prime}\right)_{2}(\mathbf{1 0})$, although its preparation involved a different synthetic route (vide infra). ${ }^{27}$

\section{Results and discussion}

The general synthetic protocol for preparing the anionic lanthanide sandwich complexes is outlined in Scheme 3. The synthesis starts with the well-established preparation of 1,4-bis(trimethylsilyl)cycloocta-2,5,7-triene from 1,5-cyclooctadiene according to Cloke et al. ${ }^{10}$ The dilithium reagent $\mathrm{Li}_{2} \mathrm{COT}^{\prime \prime}$ can be conveniently prepared by metalation of 1,4-bis(trimethylsilyl)cycloocta2,5,7-triene with $n$-butyllithium, ${ }^{10}$ and the resulting solutions can be used in situ for further reactions. However, it is also possible to isolate crystalline adducts of $\mathrm{Li}_{2} \mathrm{COT}^{\prime \prime}$, e.g. $[\mathrm{Li}(\mathrm{TMEDA})]_{2}\left(\mathrm{COT}^{\prime \prime}\right)$ $\left(\right.$ TMEDA $=N, N, N^{\prime}, N^{\prime}$-tetramethylethylenediamine $),{ }^{10 c}[\mathrm{Li}(\mathrm{DME})]_{2^{-}}$ $\left(\mathrm{COT}^{\prime \prime}\right){ }^{28 a}$ and $\left[\mathrm{Li}(\mathrm{THF})_{2}\right]_{2}\left[\mathrm{Li}_{2}\left(\mathrm{COT}^{\prime \prime}\right)_{2}\right]^{28 b}$ The latter two adducts have been structurally characterized through X-ray diffraction. $[\mathrm{Li}(\mathrm{TMEDA})]_{2}\left(\mathrm{COT}^{\prime \prime}\right)$ was shown to be an inverse sandwich complex with the two $\mathrm{Li}^{+}$ions coordinated to the bridging 1,4-bis(trimethylsilyl)cyclooctatetraene dianion ring in an $\eta^{3}$-allyllike fashion. ${ }^{28 a}\left[\mathrm{Li}(\mathrm{THF})_{2}\right]_{2}\left[\mathrm{Li}_{2}\left(\mathrm{COT}^{\prime \prime}\right)_{2}\right]$ contains two $\mathrm{Li}^{+}$ions sandwiched between two $\mathrm{COT}^{\prime \prime}$ rings and two $\mathrm{Li}(\mathrm{THF})_{2}{ }^{+}$units attached to the outside of the $\mathrm{COT}^{\prime \prime}$ rings. ${ }^{28 b}$ In the present study, however, it was found to be more convenient to use in situ-prepared THF solutions of $\mathrm{Li}_{2} \mathrm{COT}^{\prime \prime}$ rather than isolated samples. Accordingly, the anionic lanthanide sandwich complexes 1-8 were prepared by treatment of selected anhydrous lanthanide trichlorides, $\mathrm{LnCl}_{3}$, with 2 equiv. of $\mathrm{Li}_{2} \mathrm{COT}^{\prime \prime}$ in THF solution as outlined in Scheme 3. In the case of the THF adducts $\left[\mathrm{Li}(\mathrm{THF})_{4}\right]\left[\operatorname{Ln}\left(\mathrm{COT}^{\prime \prime}\right)_{2}\right](\operatorname{Ln}=\mathrm{Ho}(5), \mathrm{Tm}(7))$, 


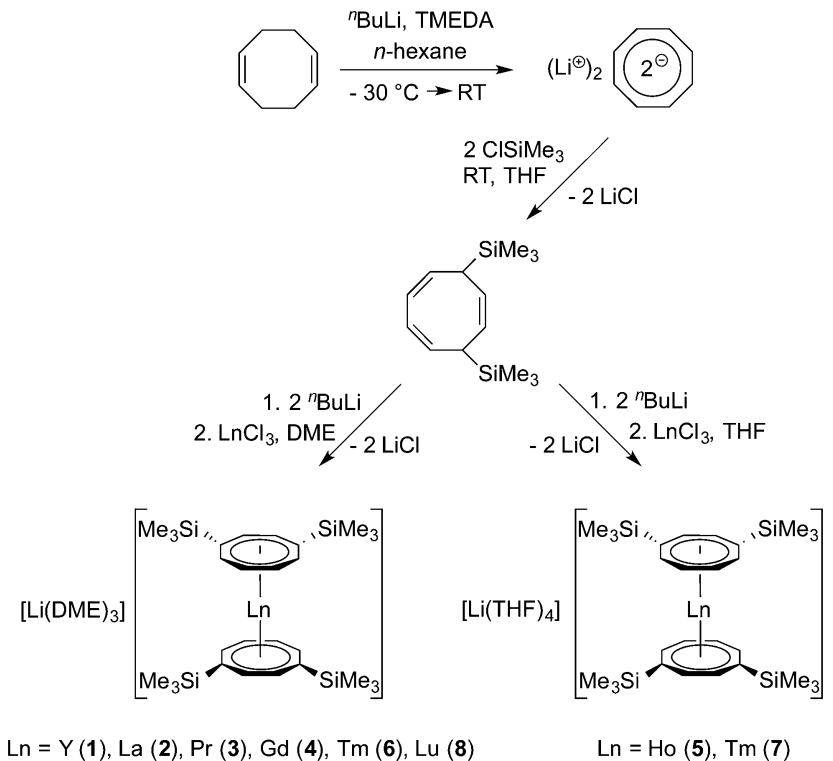

Scheme 3 Synthetic route to the anionic lanthanide sandwich complexes 1-8.

purification was achieved by recrystallization of the crude products from toluene. The DME adducts $\left[\mathrm{Li}(\mathrm{DME})_{3}\right][\mathrm{Ln}-$ $\left.\left(\mathrm{COT}^{\prime \prime}\right)_{2}\right](\mathrm{Ln}=\mathrm{Y}(\mathbf{1}), \mathrm{La}(\mathbf{2}), \operatorname{Pr}(\mathbf{3}), \mathrm{Gd}(\mathbf{4}), \mathrm{Tm}(\mathbf{6}), \mathrm{Lu}(\mathbf{8}))$ were obtained by extraction of the reaction products with toluene followed by recrystallization from DME after addition of $n$-pentane. The products were isolated in moderate to good yields (57-75\%) in the form of yellow or yellow-green (Tm: red), highly air-sensitive crystalline solids. It has been noted earlier that DME is the solvent of choice for crystallizing these anionic lanthanide sandwich complexes. ${ }^{14,20}$ The DME solvates are readily crystallized and the resulting crystals do not lose DME even under vacuum or upon prolonged storage in the dry-box. In contrast, crystals of the THF adducts are less stable with respect to loss of solvent and become opaque upon storing in the dry-box.

Meaningful NMR spectra could be obtained only for the diamagnetic products $\left[\mathrm{Li}(\mathrm{DME})_{3}\right]\left[\mathrm{Y}\left(\mathrm{COT}^{\prime \prime}\right)_{2}\right](\mathbf{1}),\left[\mathrm{Li}(\mathrm{DME})_{3}\right]\left[\mathrm{La}\left(\mathrm{COT}^{\prime \prime}\right)_{2}\right]$
(2), and $\left[\mathrm{Li}(\mathrm{DME})_{3}\right]\left[\mathrm{Lu}\left(\mathrm{COT}^{\prime \prime}\right)_{2}\right](8)$ as well as for the paramagnetic praseodymium derivative 3 . In all four cases the ${ }^{1} \mathrm{H}$ and ${ }^{13} \mathrm{C}$ NMR data were in good agreement with the formation of the expected anionic sandwich complexes. The observation of only one signal in the ${ }^{29}$ Si NMR spectra (1: $0.7 \mathrm{ppm}, 2: 0.5 \mathrm{ppm}$, 3: $-46 \mathrm{ppm}, 8: 0.8 \mathrm{ppm}$ ) indicated high purity of the materials. Moreover, the IR spectra of the DME adducts on one hand and the THF adducts on the other hand were found to be almost superimposable. All the new complexes were structurally characterized through single-crystal X-ray crystallography. Crystallographic data for 1-8 are summarized in Tables 1 and 2 . The most significant bond lengths and angles are listed in Table 3.

All eight lanthanide complexes were found to form large crystals quite readily. X-ray quality single-crystals of the DME solvates $\left[\mathrm{Li}(\mathrm{DME})_{3}\right]\left[\operatorname{Ln}\left\{\mathrm{C}_{8} \mathrm{H}_{6}\left(\mathrm{SiMe}_{3}\right)_{2}\right\}_{2}\right] \mathrm{Ln}=\mathrm{Y}(\mathbf{1}), \mathrm{La}(2), \operatorname{Pr}(\mathbf{3})$, Gd (4), Tm (6), Lu (8) were obtained by recrystallization from solvent mixtures of DME and $n$-pentane $(1: 1)$ at room temperature. Single-crystals of the THF adducts $\left[\mathrm{Li}(\mathrm{THF})_{4}\right]\left[\mathrm{Ln}\left(\mathrm{COT}^{\prime \prime}\right)_{2}\right]$ ( $\mathrm{Ln}=\mathrm{Ho}(5), \mathrm{Tm}(7))$ were grown from concentrated solutions in THF at r.t. The molecular structure of the THF adduct $\left[\mathrm{Li}(\mathrm{THF})_{4}\right]\left[\mathrm{Ho}\left(\mathrm{COT}^{\prime \prime}\right)_{2}\right](5)$ is shown in Fig. 1, and Fig. 2 shows the molecular structure of $\left[\mathrm{Li}(\mathrm{DME})_{3}\right]\left[\mathrm{Lu}\left(\mathrm{COT}^{\prime \prime}\right)_{2}\right](8)$ as a representative DME adduct.

As can be seen from Table 3, the average Ln-C bond lengths vary between $2.785 \AA$ in the lanthanum complex 2 and $2.609 \AA$ in the lutetium derivative 8. The difference of $0.176 \AA$ can be attributed to the lanthanide contraction. Certainly the most significant result is the finding that all known $\left[\mathrm{Li}(\mathrm{DME})_{3}\right]-$ $\left[\operatorname{Ln}\left(\mathrm{COT}^{\prime \prime}\right)_{2}\right]$ complexes $\left(\mathrm{Ln}=\mathrm{Y}(\mathbf{1}), \mathrm{La}(2), \mathrm{Ce}^{14,20} \operatorname{Pr}(\mathbf{3}), \mathrm{Nd},{ }^{27}\right.$ Gd (4), Dy, $\left.{ }^{17} \mathrm{Er},{ }^{21} \mathrm{Tm}(6), \mathrm{Lu}(8)\right)$ and also the recently reported $\left[\mathrm{Li}(\mathrm{DME})_{3}\right]\left[\mathrm{U}\left(\mathrm{COT}^{\prime \prime}\right)_{2}\right]^{27}$ crystallize in the triclinic space group $P \overline{\mathbf{1}}$ and are isostructural. The same can be said about the series of known $\left[\mathrm{Li}(\mathrm{THF})_{4}\right]\left[\operatorname{Ln}\left(\mathrm{COT}^{\prime \prime}\right)_{2}\right]$ complexes, ${ }^{14,17,19}$ including the new derivatives $\left[\mathrm{Li}(\mathrm{THF})_{4}\right]\left[\mathrm{Ho}\left(\mathrm{COT}^{\prime \prime}\right)_{2}\right](5)$ and (b) $\left[\mathrm{Li}(\mathrm{THF})_{4}\right]\left[\mathrm{Tm}\left(\mathrm{COT}^{\prime \prime}\right)_{2}\right]$ (7). The Ctr-Ln-Ctr angles $($ Ctr $=$ ring centroid) are found to be in the very narrow range between $177.8^{\circ}$ for $\left[\mathrm{Li}(\mathrm{THF})_{4}\right]\left[\mathrm{Tm}\left(\mathrm{COT}^{\prime \prime}\right)_{2}\right](7)$ and $175.59^{\circ}$ for

Table 1 Crystallographic data for $\mathbf{1 - 6}$

\begin{tabular}{|c|c|c|c|c|c|c|}
\hline & 1 & 2 & 3 & 4 & 5 & 6 \\
\hline Empirical formula & $\mathrm{C}_{40} \mathrm{H}_{78} \mathrm{LiO}_{6} \mathrm{Si}_{4} \mathrm{Y}$ & $\mathrm{C}_{40} \mathrm{H}_{78} \mathrm{LaLiO}_{6} \mathrm{Si}_{4}$ & $\mathrm{C}_{40} \mathrm{H}_{78} \mathrm{LiO}_{6} \mathrm{PrSi}_{4}$ & $\mathrm{C}_{40} \mathrm{H}_{78} \mathrm{GdLiO}_{6} \mathrm{Si}_{4}$ & $\mathrm{C}_{44} \mathrm{H}_{80} \mathrm{HoLiO}_{4} \mathrm{Si}_{4}$ & $\mathrm{C}_{40} \mathrm{H}_{78} \mathrm{LiO}_{6} \mathrm{Si}_{4} \mathrm{Tm}$ \\
\hline 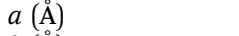 & $11.445(2)$ & $11.557(2)$ & $11.532(2)$ & $11.428(2)$ & $11.358(2)$ & $11.410(2)$ \\
\hline$b(\AA)$ & $12.219(2)$ & $12.262(3)$ & $12.286(3)$ & $12.216(2)$ & $11.657(2)$ & $12.239(2)$ \\
\hline$c(\AA)$ & $18.477(4)$ & $18.340(4)$ & $18.388(4)$ & $18.406(4)$ & $19.603(4)$ & $18.503(4)$ \\
\hline$\alpha\left(^{\circ}\right)$ & $99.13(3)$ & $98.83(3)$ & $98.82(3)$ & $98.84(3)$ & $87.12(3)$ & $99.12(3)$ \\
\hline$\beta\left(^{\circ}\right)$ & $102.20(3)$ & $102.56(3)$ & $102.49(3)$ & $102.36(3)$ & $82.38(3)$ & $102.17(3)$ \\
\hline$\gamma\left({ }^{\circ}\right)$ & $99.68(3)$ & $98.57(3)$ & $99.04(3)$ & $99.44(3)$ & $77.39(3)$ & $100.11(3)$ \\
\hline$V\left(\AA^{3}\right)$ & $2438.7(8)$ & 2461.6(9) & 2464.1(9) & $2428.0(8)$ & 2509.9(9) & $2434.9(8)$ \\
\hline$Z$ & 2 & 2 & 2 & 2 & 2 & 2 \\
\hline Formula weight & 863.23 & 913.23 & 915.23 & 931.57 & 957.31 & 943.25 \\
\hline Space group & $P \overline{1}$ & $P \overline{1}$ & $P \overline{1}$ & $P \overline{1}$ & $P \overline{1}$ & $P \overline{1}$ \\
\hline$T(\mathrm{~K})$ & $153(2)$ & $133(2)$ & $153(2)$ & $133(2)$ & $153(2)$ & $153(2)$ \\
\hline$\lambda(\AA)$ & 0.71073 & 0.71073 & 0.71073 & 0.71073 & 0.71073 & 0.71073 \\
\hline$D_{\text {calcd }}\left(\mathrm{g} \mathrm{cm}^{-3}\right)$ & 1.176 & 1.232 & 1.234 & 1.274 & 1.267 & 1.287 \\
\hline$\mu\left(\mathrm{mm}^{-1}\right)$ & 1.332 & 1.003 & 1.124 & 1.503 & 1.707 & 1.959 \\
\hline$R\left(F_{\mathrm{o}}\right.$ or $\left.F_{\mathrm{o}}^{2}\right)$ & 0.0467 & 0.0381 & 0.0267 & 0.0333 & 0.0491 & 0.0319 \\
\hline$R_{\mathrm{w}}\left(F_{\mathrm{o}}\right.$ or $\left.F_{\mathrm{o}}^{2}\right)$ & 0.1018 & 0.0944 & 0.0662 & 0.0883 & 0.0859 & 0.0771 \\
\hline
\end{tabular}


Table 2 Crystallographic data for 7-12

\begin{tabular}{|c|c|c|c|c|c|c|}
\hline & 7 & 8 & 9 & 10 & 11 & 12 \\
\hline Empirical formula & $\mathrm{C}_{44} \mathrm{H}_{80} \mathrm{LiO}_{4} \mathrm{Si}_{4} \mathrm{Tm}$ & $\mathrm{C}_{40} \mathrm{H}_{78} \mathrm{LiLuO}_{6} \mathrm{Si}_{4}$ & $\mathrm{C}_{28} \mathrm{H}_{48} \mathrm{Si}_{4} \mathrm{Th}$ & $\mathrm{C}_{28} \mathrm{H}_{48} \mathrm{Si}_{4} \mathrm{U}$ & $\mathrm{C}_{34} \mathrm{H}_{64} \mathrm{Si}_{6} \mathrm{Th}$ & $\mathrm{C}_{34} \mathrm{H}_{64} \mathrm{Si}_{6} \mathrm{U}$ \\
\hline$a(\AA)$ & $11.358(2)$ & $11.471(2)$ & $9.830(3)$ & $12.6598(12)$ & $20.9990(12)$ & $23.381(3)$ \\
\hline$b(\AA)$ & $11.657(2)$ & $12.051(2)$ & $9.898(3)$ & $20.3542(18)$ & $25.1674(15)$ & $21.170(3)$ \\
\hline$c(\AA)$ & $19.603(4)$ & $18.459(4)$ & $17.038(5)$ & $24.645(2)$ & $17.8458(10)$ & $18.125(2)$ \\
\hline$\alpha\left(^{\circ}\right)$ & $87.12(3)$ & $99.79(3)$ & $79.262(4)$ & 90 & 90 & 90 \\
\hline$\beta\left(^{\circ}\right)$ & $82.38(3)$ & $101.72(3)$ & $80.692(4)$ & 90 & $114.3160(10)$ & $107.923(2)$ \\
\hline$\gamma\left({ }^{\circ}\right)$ & $77.39(3)$ & $100.05(3)$ & $80.891(3)$ & 90 & 90 & 90 \\
\hline$V\left(\AA^{3}\right)$ & 2509.9(9) & $2403.6(8)$ & $1.5932(8)$ & $6350.6(10)$ & $8594.7(9)$ & $8536.3(18)$ \\
\hline$Z$ & 2 & 2 & 2 & 8 & 8 & 8 \\
\hline Formula weight & 961.31 & 949.29 & 729.06 & 735.05 & 873.43 & 879.42 \\
\hline Space group & $P \overline{1}$ & $P \overline{1}$ & $P \overline{1}$ & Pbca & $\mathrm{C} 2 / c$ & $P 2_{1} / c$ \\
\hline$T(\mathrm{~K})$ & $153(2)$ & $143(2)$ & $100(2)$ & $173(2)$ & $200(2)$ & $200(2)$ \\
\hline$\lambda(\AA)$ & 0.71073 & 0.71073 & 0.71073 & 0.71073 & 0.71073 & 0.71073 \\
\hline$D_{\text {calcd }}\left(\mathrm{g} \mathrm{cm}^{-3}\right)$ & 1.272 & 1.312 & 1.520 & 1.538 & 1.350 & 1.369 \\
\hline$\mu\left(\mathrm{mm}^{-1}\right)$ & 1.899 & 2.192 & 4.845 & 5.277 & 3.657 & 3.991 \\
\hline$R\left(F_{\mathrm{o}}\right.$ or $\left.F_{\mathrm{o}}^{2}\right)$ & 0.0390 & 0.0557 & 0.0472 & 0.0238 & 0.0301 & 0.0421 \\
\hline$R_{\mathrm{w}}\left(F_{\mathrm{o}}\right.$ or $\left.F_{\mathrm{o}}^{2}\right)$ & 0.1015 & 0.1473 & 0.1084 & 0.0838 & 0.0675 & 0.1127 \\
\hline
\end{tabular}

Table 3 Selected average bond lengths $(\AA)$ and angles $\left(^{\circ}\right)$ of the lanthanide sandwich complexes $\mathbf{1 - 8}$. Ctr stands for the COT" ring centroids

\begin{tabular}{lllllllll}
\hline & Y (1) & La (2) & $\operatorname{Pr}(3)$ & Gd (4) & Ho (5) & Tm (6) & Tm (7) & Lu (8) \\
\hline Ln-C & 2.649 & 2.785 & 2.740 & 2.680 & 2.607 & 2.624 & 2.615 & 2.609 \\
C-C & 1.413 & 1.414 & 1.414 & 1.416 & 1.414 & 1.417 & 1.414 & 1.412 \\
Si-C & 1.865 & 1.867 & 1.866 & 1.867 & 1.868 & 1.867 & 1.868 & 1.864 \\
Li-O & 2.135 & 2.133 & 2.134 & 2.134 & 1.921 & 2.135 & 1.919 & 2.123 \\
Ln-Ctr & 1.900 & 2.084 & 2.020 & 1.940 & 1.873 & 1.861 & 1.850 & 1.845 \\
Ctr-Ln-Ctr & 176.19 & 175.59 & 175.80 & 175.74 & 177.6 & 176.6 & 177.8 & 176.86
\end{tabular}

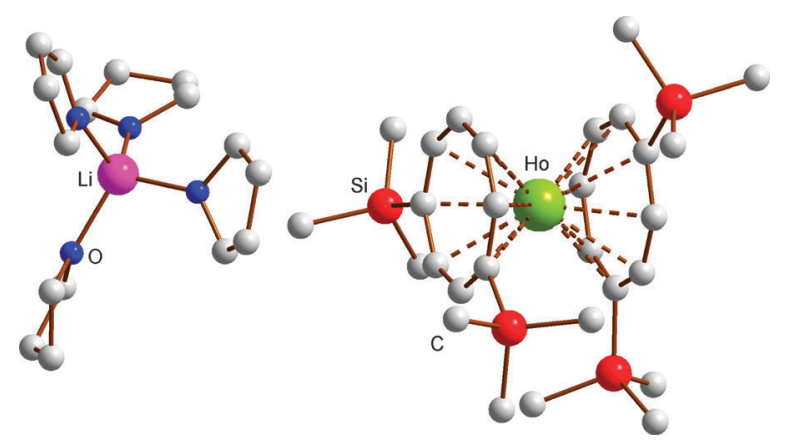

Fig. 1 Molecular structure of $\left[\mathrm{Li}(\mathrm{THF})_{4}\right]\left[\mathrm{Ho}\left(\mathrm{COT}^{\prime \prime}\right)_{2}\right](\mathbf{5})$.

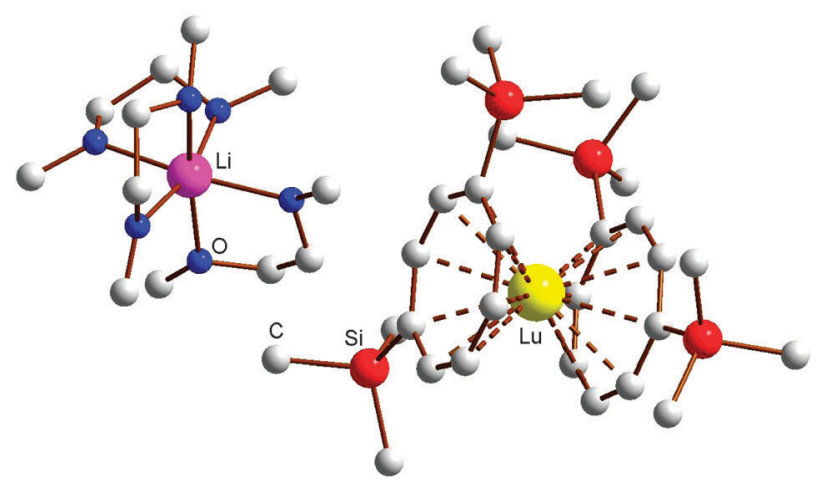

Fig. 2 Molecular structure of $\left.\left[\mathrm{Li}(\mathrm{DME})_{3}\right]\left[\mathrm{Lu}_{(\mathrm{COT}}\right)_{2}\right](\mathbf{8})$.
$\left[\mathrm{Li}(\mathrm{DME})_{3}\right]\left[\operatorname{Ln}\left(\mathrm{COT}^{\prime \prime}\right)_{2}\right]$ (2). Thus there is only little deviation from the ideal linear sandwich arrangement. Clearly, the bulky cyclooctatetraenyl ligand $\mathrm{COT}^{\prime \prime}$ is ideally suited for studying homologous series of lanthanide and actinide sandwich complexes comprising the full range of ionic radii possible. Table 4 provides an overview of all anionic lanthanide sandwich complexes of the types $\left[\mathrm{Li}(\mathrm{THF})_{4}\right]\left[\mathrm{Ln}\left(\mathrm{COT}^{\prime \prime}\right)_{2}\right]$ and $\left[\mathrm{Li}(\mathrm{DME})_{3}\right]-$ $\left[\operatorname{Ln}\left(\mathrm{COT}^{\prime \prime}\right)_{2}\right]$ reported thus far in order to show which gaps have been filled by the present study.

In a similar manner, the closely related neutral actinidocenes $\mathrm{An}\left(\mathrm{COT}^{\prime \prime}\right)_{2}(\mathrm{An}=\mathrm{Th}(\mathbf{9}), \mathrm{U}(\mathbf{1 0}))$ have also been prepared. As outlined in Scheme 4, these sandwich complexes were prepared in a straightforward manner by reaction of anhydrous $\mathrm{ThCl}_{4}$ or $\mathrm{UCl}_{4}$ with 2 equiv. of in situ-prepared $\mathrm{Li}_{2} \mathrm{COT}^{\prime \prime}$. Due to the high solubility of all the reactants in THF, the reactions were finished after $2 \mathrm{~h}$ stirring at r.t. In contrast, reactions of $\mathrm{AnCl}_{4}$ with the unsubstituted $\mathrm{K}_{2} \mathrm{COT}$ normally take days. ${ }^{11,12}$ Bright yellow $\mathrm{Th}\left(\mathrm{COT}^{\prime \prime}\right)_{2}(9)$ and dark green (dichroitic red/green) $\mathrm{U}\left(\mathrm{COT}^{\prime \prime}\right)_{2}(\mathbf{1 0})$ were both isolated in high yields of $c a .80 \%$. Purification could be achieved either by highvacuum sublimation at $240{ }^{\circ} \mathrm{C}$ or by slow crystallization from the oily crude products. In this context it is interesting to note that Murugesu et al. very recently prepared compound 10 via a two-step synthesis where $\mathrm{U}^{\mathrm{III}} \mathrm{I}_{3}$ (1,4-dioxane) $)_{1.5}$ and $\left[\mathrm{Li}(\mathrm{THF})_{2}\right]_{2}\left[\mathrm{Li}_{2}\left(\mathrm{COT}^{\prime \prime}\right)_{2}\right]^{28 b}$ were first combined in THF to afford the anionic uranium(III) sandwich complex [Li(DME) 3 ]$\left[\mathrm{U}\left(\mathrm{COT}^{\prime \prime}\right)_{2}\right]$ which was then oxidized to the uranium(Iv) sandwich 10 using $\mathrm{FeCl}_{2} .{ }^{27}$

For comparison, two neutral actinide sandwich complexes comprising the bulky 1,3,6-tris(trimethylsilyl)cyclooctatetraenyl ligand $\left(\mathrm{COT}^{\prime \prime \prime}\right)$ have also been prepared. These compounds have earlier been mentioned in two communications, but structural characterization through X-ray diffraction was lacking. ${ }^{24}$ Both compounds were prepared according to the straightforward synthetic protocol illustrated in Scheme 5. In this case, the use of the potassium precursor $\mathrm{K}_{2} \mathrm{COT}^{\prime \prime \prime}$ provided products 11 and 12 in yields of around $80 \%$ after crystallization from concentrated solutions in $n$-pentane. Like their tetrasubstituted 
Table 4 Overview of all known anionic lanthanide sandwich complexes of the type $\left[\mathrm{Li}(\mathrm{THF})_{4}\right]\left[\mathrm{Ln}\left(\mathrm{COT}^{\prime \prime}\right)_{2}\right]\left(\right.$ denoted THF) and $\left[\mathrm{Li}(\mathrm{DME})_{3}\right]\left[\mathrm{Ln}(\mathrm{COT})_{2}\right]$ (denoted DME). $\mathbf{X}$ : compounds described in this work

\begin{tabular}{|c|c|c|c|c|c|c|c|c|c|c|c|c|c|c|c|}
\hline Ln & $\mathrm{Y}$ & $\mathrm{La}$ & $\mathrm{Ce}$ & $\operatorname{Pr}$ & $\mathrm{Nd}$ & $\mathrm{Sm}$ & $\mathrm{Eu}$ & $\mathrm{Gd}$ & $\mathrm{Tb}$ & Dy & Ho & Er & $\mathrm{Tm}$ & $\mathrm{Yb}$ & $\mathrm{Lu}$ \\
\hline
\end{tabular}

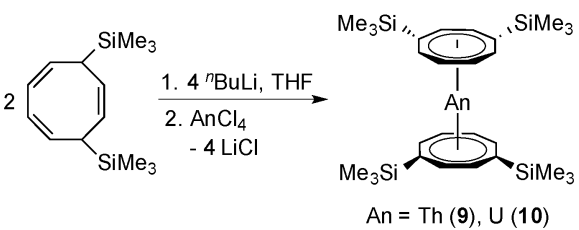

Scheme 4 Synthetic route to the neutral actinidocenes $A n\left(\mathrm{COT}^{\prime \prime}\right)_{2}(\mathrm{An}=$ Th (9), U (10)).

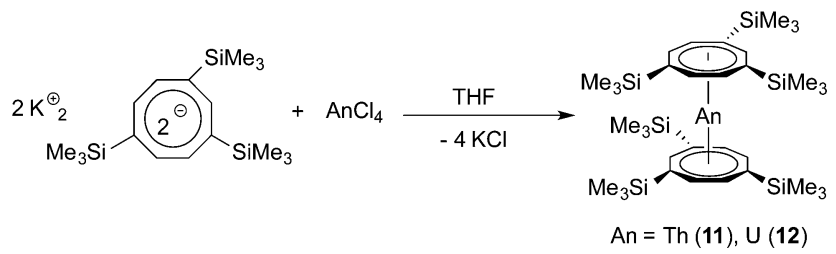

Scheme 5 Synthesis of the neutral actinidocenes $A n\left(\mathrm{COT}^{\prime \prime \prime}\right)_{2}(\mathrm{An}=\mathrm{Th}$ (11), U (12)).

congeners 9 and 10, thorium compound 11 forms bright yellow crystals, while crystals of $\mathbf{1 2}$ appear dichroitic red/green. Both complexes are highly soluble in common organic solvents, including hydrocarbons.

All four silyl-substituted actinidocenes 9-12 have been structurally characterized through single-crystal X-ray diffraction. Crystallographic data for 9-12 are summarized in Table 2; selected bond lengths and angles are listed in Table 4. The molecular structures are depicted in Fig. 3 and 4. As can be seen from the structural data listed in Table 4 , the overall structural features of all four actinidocene derivatives studied here are very similar. According to the unsymmetrical substitution pattern on the cyclooctatetraenyl rings leading to steric interactions, all complexes show a slight distorsion from the ideal linear arrangement with Ctr-M-Ctr angles of about $174^{\circ}$. As expected, evidence for actinide contraction is found which is
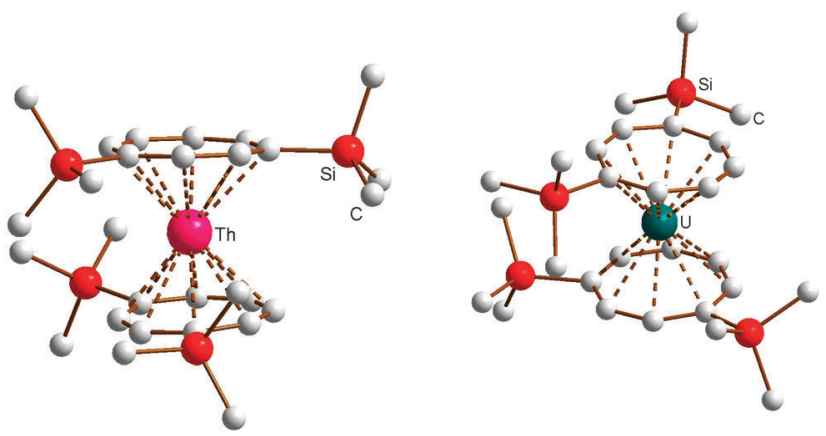

Fig. 3 Molecular structures of Th(COT" $)_{2}(\mathbf{9})$ and U(COT" $)_{2}(\mathbf{1 0})$.
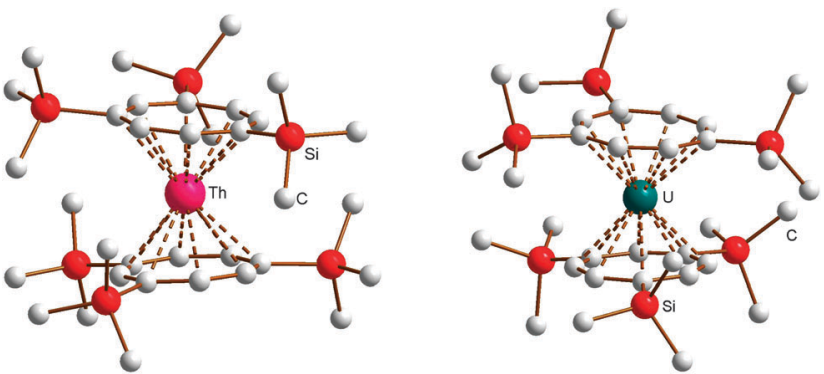

Fig. 4 Molecular structures of $\operatorname{Th}\left(\mathrm{COT}^{\prime \prime \prime}\right)_{2}(\mathbf{1 1})$ and $\mathrm{U}\left(\mathrm{COT}^{\prime \prime \prime}\right)_{2}$ (12).

Table 5 Selected average bond lengths $(\AA)$ and angles $\left(^{\circ}\right)$ of the actinide sandwich complexes 9-12. Ctr stands for the COT ring centroids; mean values are given in parentheses

\begin{tabular}{lllll}
\hline & Th $(\mathbf{9})$ & $\mathrm{U}(\mathbf{1 0})$ & Th $(\mathbf{1 1})$ & $\mathrm{U}(\mathbf{1 2})$ \\
\hline $\mathrm{M}-\mathrm{C}$ & $2.696-2.745$ & $2.642-269.0$ & $2.709-2.763$ & $2.643-2.727$ \\
& $(2.718)$ & $(2.663)$ & $2.705-2.762$ & $2.647-2.727$ \\
& & & $(2.735 / 2.732)$ & $(2.679 / 2.681)$ \\
$\mathrm{M}-$ Ctr & 1.987 & $1.921 / 1.913$ & 2.012 & $1.942,1.944$ \\
& 1.999 & $(1.917)$ & 2.010 & $1.938,1.945$ \\
& $(1.993)$ & & $(2.011)$ & $(1.942)$ \\
Ctr-M-Ctr & 172.9 & 173.0 & $174.3,175.3$ & $174.3,174.9$ \\
Pl/Pl & 7.1 & 7.4 & 6.3 & $5.7 / 6.0$
\end{tabular}

reflected in $\sim 5 \mathrm{pm}$ shorter $\mathrm{M}-\mathrm{C}$ as well as in $\sim 7 \mathrm{pm}$ shorter $\mathrm{M}-\mathrm{Ctr}$ distances in the uranium complexes as compared to the thorium species (Table 5).

In the following, the structural and spectroscopic characterization of $\mathbf{1 0}$ as a typical example will be discussed in more detail. The molecular structure of $\mathbf{1 0}$ can be clearly described as being of the well-known uranocene type (Fig. 5). Accordingly, in the molecular structure the central uranium atom is placed between the two cyclooctatetraenyl rings with U-Ctr distances of 1.913 or $1.921 \AA$, comparable to previously reported uranocene derivatives $^{29}$ (Table 4). However, the trimethylsilyl substituents in 1,4-positions of the cyclooctatetraenyl ring lead to an arrangement in the solid state where on one side of the molecule a stronger steric interaction between the two cyclooctatetraenyl rings results. Si1 and $\mathrm{Si} 4$ are found to be in closer steric environment than $\mathrm{Si} 2$ and $\mathrm{Si} 3$, giving rise to a significant repulsion on this side of the rings. This has an influence on the bond lengths and angles in that the two cyclooctatetraenyl rings do not bind symmetrically to the central uranium atom. The $\mathrm{U}-\mathrm{C}$ bond distances cover a range between 2.642 and 2.690(4) $\AA$ with the longer bond lengths found on the side with the stronger steric interactions, whereas the shortest $\mathrm{U}-\mathrm{C}$ bond length is observed for U1-C22 with 2.642(4) A. Accordingly, the two cyclooctatetraenyl rings are not coordinated coplanar with 


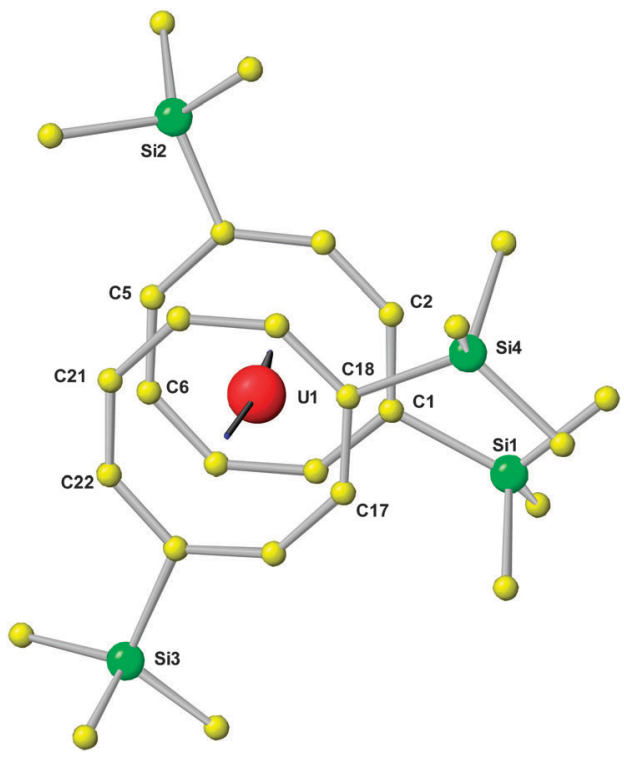

Fig. 5 Top view of the molecular structure of $U\left(\mathrm{COT}^{\prime \prime}\right)_{2}(\mathbf{1 0})$.

respect to the uranium center. This results in a Ctr-U-Ctr angle of $7.0^{\circ}$ and a tilt angle between the two ring planes of $7.4^{\circ}$ with the opening to the side of Si1/Si4 (Table 4 and Fig. 5). This is further reflected in the corresponding distances between opposing carbon atoms of the two COT" rings in the staggered structure. With 4.047 and $4.070 \AA$ the distances $\mathrm{C} 1-\mathrm{C} 17$ and C2-C18 are remarkably longer than those between C5 and C21 or C6 and C22, which are with 3.627 or $3.614 \AA$ significantly shorter. These structural findings clearly show that compound 10 shows typical uranocene structural features ${ }^{29 a}$ but with a significant distorsion caused by steric effects due to the trimethylsilyl substituents at the COT rings. A significantly stronger tilting of the two cyclooctatetraenyl rings has been observed in the 1,4-bis(triphenylsilyl)-substituted system where ring-to-ring C-C distances between 3.468 and $4.247 \AA$ and a tilt angle of $11.4^{\circ}$ have been found. ${ }^{30}$

The spectroscopic data of the complexes 9-12 are in good agreement with their structural features. As expected, the IR spectra of 9-12 are all very similar, showing the comparable molecular constitution of these actinidocenes. Frequencies arising from the $\mathrm{COT}^{\prime \prime}$ ligand increase slightly upon complexation as compared to $\mathrm{K}_{2} \mathrm{COT}^{\prime \prime}$. However, the spectra are more complicated than those of the unsubstituted actinidocenes as the $\mathrm{SiMe}_{3}$-substituents give rise to strong absorptions themselves and cause a distorsion from the ideal $D_{8 \mathrm{~h}}$-symmetry observed in the actinidocenes, leading to a higher number of observed frequencies. ${ }^{31}$ However, the general congruency of the IR and FIR spectra clearly shows the similarity in the structural features of the complexes 9-12. The other spectroscopic data will be highlighted taking again compound $\mathbf{1 0}$ as example. In contrast to the corresponding Th-complex $\mathbf{9}$, the uranocene derivative $\mathbf{1 0}$ exhibits a $5 \mathrm{f}^{2}$-electron configuration causing paramagnetism and an intensely red color in transmission. These findings are confirmed by the UV-vis data (Fig. 6), showing that below $450 \mathrm{~nm}$ the absorption of the complex is strongly increasing.
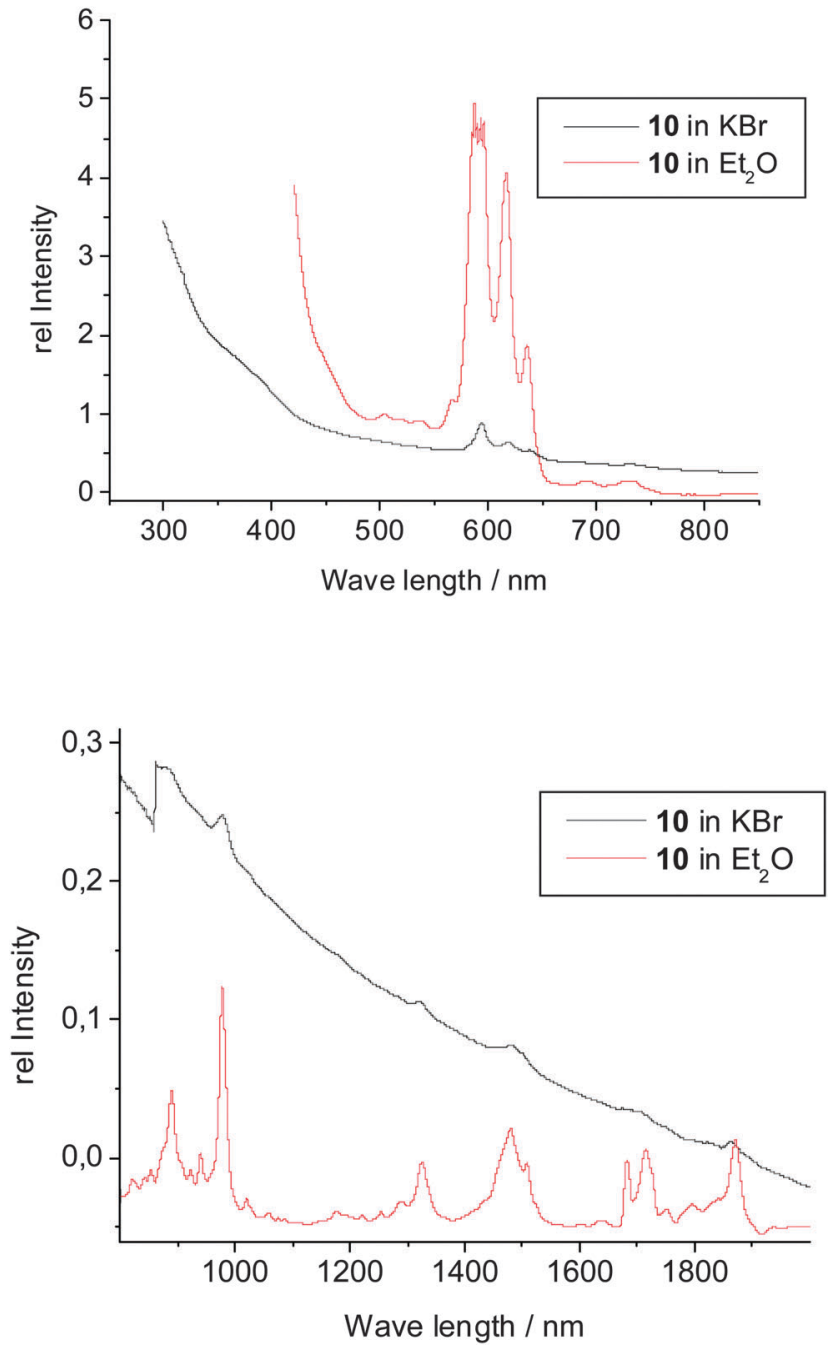

Fig. 6 UV-vis spectra of U(COT" $)_{2}(10)$.

The absorptions at 592, 618, $635 \mathrm{~nm}$ are caused by strong charge transfer transitions typical for actinocene complexes, however being more intense in symmetry-distorted systems. ${ }^{32}$ In the range of 800 to $2000 \mathrm{~nm}$, the UV-vis spectrum does not show any significant differences between the solid state and the solution, indicating that the solid state structure is retained in solution and no adduct formation takes place. Accordingly, the absorptions at 980, 1322, 1486, 1710, 1755, 1793, $1865 \mathrm{~nm}$ are caused by f-f transitions, which are characteristic of U(Iv)-organometallics. ${ }^{33}$ The $\mathrm{f}-\mathrm{f}$ transitions are in this case of higher intensity than for the unsubstituted uranocene due to the observed distortion of the complex symmetry by the $\mathrm{SiMe}_{3}$ substituents, which causes an increase in the intensity for the symmetry-forbidden $f-f$ transitions. These are, however, between 10 to 100 times less intense than the charge transfer absorptions.

The paramagnetism of $\mathbf{1 0}$ is also clearly seen from its NMR data (Fig. 7-9), where for all signals a typical upfield shift is observed. ${ }^{7 a, 34}$ In good agreement with the solid state structure, the ${ }^{1} \mathrm{H}$ NMR spectrum of $\mathbf{1 0}$ (Fig. 7) shows four well-separated singlets at $-9.99,-25.20,-39.63$, and $-45.62 \mathrm{ppm}$. The latter three each correspond to four ring protons, whereas the first 


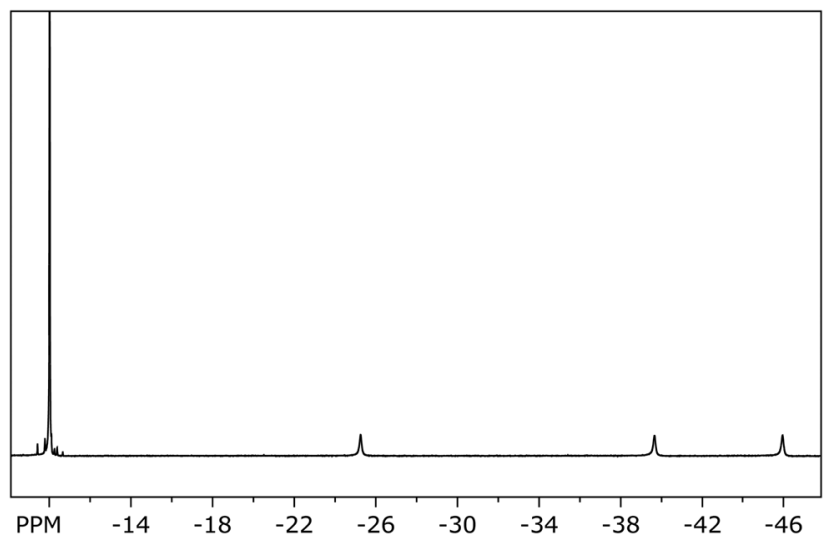

Fig. $7{ }^{1} \mathrm{H}$ NMR spectrum of $\mathrm{U}\left(\mathrm{COT}^{\prime \prime}\right)_{2}(10)$.

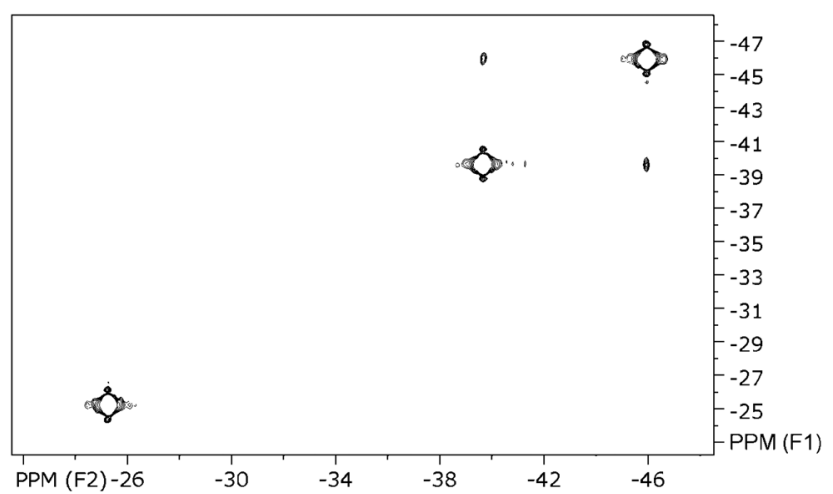

Fig. $8 \mathrm{HH}$ correlated NMR spectrum of $\mathrm{U}\left(\mathrm{COT}^{\prime \prime}\right)_{2}(\mathbf{1 0})$.

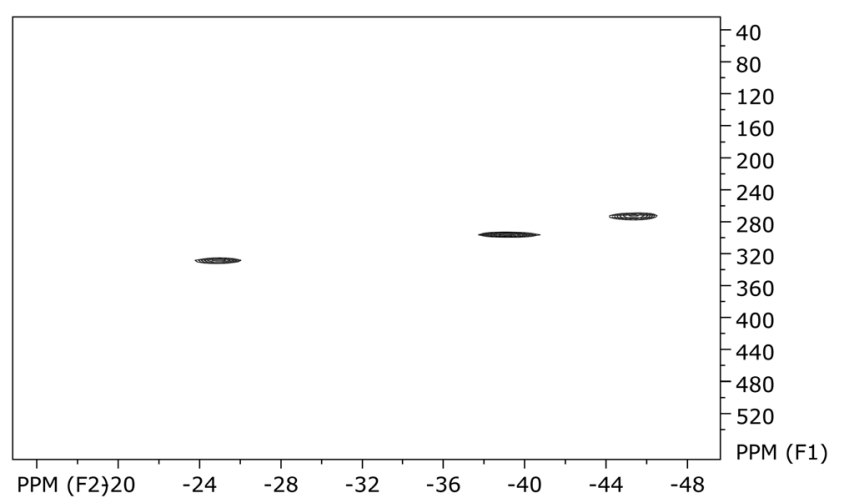

Fig. $9 \mathrm{CH}$ correlated NMR spectrum of $\mathrm{U}\left(\mathrm{COT}^{\prime \prime}\right)_{2}(\mathbf{1 0})$.

resonance can be clearly assigned to the protons of the $\mathrm{SiMe}_{3}$ substituents. In the two-dimensional $\mathrm{HH}$-correlated spectrum the resonances at -39.63 and $-45.62 \mathrm{ppm}$ ( $\beta$-position to the $\mathrm{SiMe}_{3}$-substituents) are assigned to the protons in the $(\mathrm{CH})_{4^{-}}$ chain of the $\mathrm{COT}^{\prime \prime}$ ring, whereas the resonance at $-25.20 \mathrm{ppm}$ corresponds to the ring protons positioned between the two trimethylsilyl substituents in 1,4-positions (Fig. 8).

This assignment is in good agreement with the published data where a strong influence of the paramagnetism on the chemical shifts in uranocene derivatives is described. ${ }^{34}$
However, in this paper, for the first time, the ${ }^{13} \mathrm{C}$ chemical shifts of a uranocene complex are reported. The carbon resonance of the $\mathrm{SiMe}_{3}$ groups was localized at $-3.5 \mathrm{ppm}$. The proton resonance at $-25.20 \mathrm{ppm}$ exhibits a cross peak at $325.9 \mathrm{ppm}$ in the ${ }^{13} \mathrm{C}$ frequency, whereas the two coupling $\mathrm{H}$-atoms of the aromatic ring at $-39.63 \mathrm{ppm}$ and $-45.62 \mathrm{ppm}$ give rise to carbon resonances as well at low field shifts with 293.8 and $270.3 \mathrm{ppm}$, respectively (Fig. 9). The observation of carbon frequencies at these low fields is in agreement with theoretical predictions. ${ }^{35}$

\section{Conclusions}

In summarizing the results reported here, the series of anionic lanthanide(III) sandwich complexes of the type $\left[\operatorname{Ln}\left(\mathrm{COT}^{\prime \prime}\right)_{2}\right]^{-}$ $\left(\mathrm{COT}^{\prime \prime}=1,4\right.$-bis(trimethylsilyl)cyclooctatetraenyl dianion) has been largely extended through the synthesis of eight new derivatives ranging from lanthanum to lutetium. Surprisingly, neither the ionic radius nor the oxidation state of the f-element ion $\left(\mathrm{Ln}^{3+} /\right.$ $\mathrm{An}^{4+}$ ) have a pronounced influence on the structural features of the compounds $\left[\mathrm{Li}(\mathrm{DME})_{3}\right]\left[\operatorname{Ln}\left(\mathrm{COT}^{\prime \prime}\right)_{2}\right](\mathbf{1}-\mathbf{8} ; \mathrm{Ln}=\mathrm{Y}, \mathrm{La}, \mathrm{Pr}, \mathrm{Gd}$, $\mathrm{Tm}, \mathrm{Lu}),\left[\mathrm{Li}(\mathrm{THF})_{4}\right]\left[\mathrm{Ln}\left(\mathrm{COT}^{\prime \prime}\right)_{2}\right](\mathbf{5}, 7 ; \mathrm{Ln}=\mathrm{Ho}, \mathrm{Tm}), \mathrm{An}\left(\mathrm{COT}^{\prime \prime}\right)_{2}$ $(9,10 ; \mathrm{An}=\mathrm{Th}, \mathrm{U})$ and $\mathrm{An}\left(\mathrm{COT}^{\prime \prime \prime}\right)_{2}(\mathbf{1 1}, \mathbf{1 2} ; \mathrm{An}=\mathrm{Th}, \mathrm{U})$. In all cases the slight deviation from the ideal sandwich structure is in the same range. Through this comparative study anionic sandwich complexes containing the $\left[\mathrm{Ln}\left(\mathrm{COT}^{\prime \prime}\right)_{2}\right]^{-}$anions have now become available for the entire series of rare-earth metals. This should allow for more detailed investigations e.g. of the magnetic properties in the course of future studies.

\section{Experimental section}

\subsection{General procedures}

All operations were performed with rigorous exclusion of air and water in oven-dried or flame-dried glassware under an inert atmosphere of dry argon, employing standard Schlenk, highvacuum and glovebox techniques (MBraun MBLab; $<1 \mathrm{ppm}$ $\mathrm{O}_{2},<1 \mathrm{ppm}_{2} \mathrm{O}$ ). THF, DME, toluene, and cyclopentane were dried over sodium/benzophenone and freshly distilled under a nitrogen atmosphere prior to use. All glassware was oven-dried at $120{ }^{\circ} \mathrm{C}$ for at least $24 \mathrm{~h}$, assembled while hot, and cooled under high vacuum, prior to use. The starting materials, anhydrous $\mathrm{LnCl}_{3}(\mathrm{Ln}=\mathrm{Ce}, \mathrm{Nd}),{ }^{36} \mathrm{ThCl}_{4},{ }^{37} \mathrm{UCl}_{4},{ }^{38} \mathrm{C}_{8} \mathrm{H}_{8}\left(\mathrm{SiMe}_{3}\right)_{2}{ }^{10} \mathrm{Li}_{2}\left(\mathrm{COT}^{\prime \prime}\right),{ }^{10}$ and $\mathrm{K}_{2} \mathrm{COT}^{\prime \prime \prime 24,25}$ were prepared according to the published procedures. The NMR spectra were recorded in $\mathrm{C}_{6} \mathrm{D}_{6}$ or $d_{8}$-THF solutions on a Bruker AVANCE $600\left({ }^{1} \mathrm{H}\right.$ : $600.1 \mathrm{MHz} ;{ }^{13} \mathrm{C}$ : $150.9 \mathrm{MHz})$ or a Bruker AVANCE $400\left(5 \mathrm{~mm} \mathrm{BB},{ }^{1} \mathrm{H}: 400.1 \mathrm{MHz}\right.$; ${ }^{13} \mathrm{C}: 100.6 \mathrm{MHz}$ ) (Ln compounds), or a Bruker-AVANCE 250 (5 mm TBI, ${ }^{1} \mathrm{H}: 250.1 \mathrm{MHz} ;{ }^{13} \mathrm{C}$ : $62.5 \mathrm{MHz}$ ) (An compounds). ${ }^{1} \mathrm{H}$ and ${ }^{13} \mathrm{C}$ shifts are referenced to internal solvent resonances and reported in parts per million relative to TMS. IR (KBr) spectra were recorded using a Perkin-Elmer FT-IR 2000 spectrometer. UV-Vis spectra were registered on a Perkin-Elmer Lambda 2 spectrometer. Mass spectra (EI, $70 \mathrm{eV}$ ) were run on a MAT 95 apparatus. Microanalyses of the compounds were performed 
using a Leco CHNS 932 apparatus. Metal analyses were performed via ICP AES.

\subsection{Preparation of the anionic lanthanide sandwich complexes 1-8 (general synthetic protocols)}

(a) DME solvates $\left[\mathrm{Li}(\mathrm{DME})_{3}\right]\left[\mathbf{L n}\left\{\mathrm{C}_{8} \mathrm{H}_{6}\left(\mathrm{SiMe}_{3}\right)_{2}\right\}_{2}\right](\mathrm{Ln}=\mathrm{Y}$ (1), $\mathrm{La}(2), \operatorname{Pr}(3), \mathrm{Gd}(4), \mathrm{Tm}(6), \mathrm{Lu}(8))$. $\mathrm{Li}_{2}\left(\mathrm{COT}^{\prime \prime}\right)$ was prepared in situ by adding $15.0 \mathrm{~mL}(24.0 \mathrm{mmol})$ of a $1.6 \mathrm{M} n$-butyllithium solution in $n$-hexane at r.t. to a solution of $3.0 \mathrm{~g}(12.0 \mathrm{mmol})$ $\mathrm{C}_{8} \mathrm{H}_{8}\left(\mathrm{SiMe}_{3}\right)_{2}$ in $150 \mathrm{~mL}$ of THF. $6.0 \mathrm{mmol}$ of anhydrous $\mathrm{LnCl}_{3}$ were added as a solid, the reaction mixture was stirred for $24 \mathrm{~h}$ and the solvents were completely removed under vacuum. The solid residue was extracted with $150 \mathrm{~mL}$ of toluene. After filtration, the toluene was again completely removed under vacuum and replaced by $30 \mathrm{~mL}$ of DME. After addition of the same amount of $n$-pentane, the products [Li(DME $\left.)_{3}\right]$ $\left[\operatorname{Ln}\left\{\mathrm{C}_{8} \mathrm{H}_{6}\left(\mathrm{SiMe}_{3}\right)_{2}\right\}_{2}\right]$ crystallized upon standing at room temperature for a few days.

(b) THF solvates $\left[\mathrm{Li}(\mathrm{THF})_{4}\right]\left[\operatorname{Ln}\left\{\mathrm{C}_{8} \mathrm{H}_{6}\left(\mathrm{SiMe}_{3}\right)_{2}\right\}_{2}\right](\mathrm{Ln}=\mathrm{Ho}$ (5), $\mathbf{T m}(7))$. The reactions were carried out exactly in the same manner as described above. After extraction of the products with toluene and filtration, the volume of the solution was reduced to $\sim 20 \mathrm{~mL}$. The products $\left[\mathrm{Li}(\mathrm{THF})_{4}\right]\left[\operatorname{Ln}\left\{\mathrm{C}_{8} \mathrm{H}_{6}\left(\mathrm{SiMe}_{3}\right)_{2}\right\}_{2}\right]$ crystallized directly upon standing at room temperature for a few days.

[Li(DME) $\left.)_{3}\right]\left[\mathbf{Y}\left\{\mathbf{C}_{8} \mathbf{H}_{6}\left(\mathrm{SiMe}_{3}\right)_{2}\right\}_{2}\right]$ (1). Yield: $3.57 \mathrm{~g}(69 \%)$, dec. > $90{ }^{\circ} \mathrm{C}$. Elemental analysis calcd. for $\mathrm{C}_{40} \mathrm{H}_{78} \mathrm{LiO}_{6} \mathrm{Si}_{4} \mathrm{Y}\left(M_{\mathrm{r}}=\right.$ $863.24 \mathrm{~g} \mathrm{~mol}^{-1}$ ): C, 55.66; H, 9.11. Found: C, 54.98; H, 8.88\%. IR (KBr disc): $\nu=3222 \mathrm{~m}, 3092 \mathrm{~m}, 3037 \mathrm{~m}, 2962 \mathrm{~s}, 2933 \mathrm{~s}, 2531 \mathrm{~m}$, $2360 \mathrm{~m}, 2224 \mathrm{~m}, 2029 \mathrm{~m}, 1959 \mathrm{~m}, 1638 \mathrm{vs}, 1497 \mathrm{~m}, 1445 \mathrm{~s}, 1408 \mathrm{~s}$, $1384 \mathrm{~s}, 1371 \mathrm{~s}, 1309 \mathrm{~s}, 1248 \mathrm{vs}, 1181 \mathrm{~s}, 1155 \mathrm{~s}, 1044 \mathrm{~m}, 1027 \mathrm{~m}$, 985m, 934w, 837vs, 810m, 750m, 719m, 692w, 651w, 636w, 626w, 589vw, 555w, 505w, $480 \mathrm{vw}, 457 \mathrm{vw} \mathrm{cm}{ }^{-1} .{ }^{1} \mathrm{H} \mathrm{NMR}(400.1 \mathrm{MHz}$, $d_{8}$-THF, $24{ }^{\circ} \mathrm{C}$ ): $\delta=3.40$ (s, 12H, DME), 3.26 (s, 18H, DME), 0.43 (s, 36H, $\left.\mathrm{Si}\left(\mathrm{CH}_{3}\right)_{3}\right), 6.09-6.04(\mathrm{~m}, 8 \mathrm{H}, \mathrm{COT}-H), 5.91-5.87(\mathrm{~m}, 4 \mathrm{H}$, COT- $H$ ) ppm. ${ }^{13} \mathrm{C}$ NMR $\left(100.6 \mathrm{MHz}, d_{8}\right.$-THF, $\left.24{ }^{\circ} \mathrm{C}\right): \delta=99.4$ (COT), 99.3 (СОT), 97.3 (СОT), 96.6 (COT), 72.7 (DME), 58.9 (DME), $1.6\left(\mathrm{Si}\left(\mathrm{CH}_{3}\right)_{3}\right) \mathrm{ppm} .{ }^{29} \mathrm{Si} \mathrm{NMR}\left(79.5 \mathrm{MHz}, d_{8}\right.$-THF, $\left.24{ }^{\circ} \mathrm{C}\right)$ : $\delta=0.7$ ppm. MS (EI): $m / z 586\left(26 \%,\left[\left\{\mathrm{C}_{8} \mathrm{H}_{6}\left(\mathrm{SiMe}_{3}\right)_{2}\right\}_{2} \mathrm{Y}\right]\right), 514$ (6, $\left.\left[\left\{\mathrm{C}_{8} \mathrm{H}_{6}\left(\mathrm{SiMe}_{3}\right)_{2}\right\}_{2} \mathrm{Y}-\mathrm{SiMe}_{3}\right]\right), 337\left(35,\left[\left\{\mathrm{C}_{8} \mathrm{H}_{6}\left(\mathrm{SiMe}_{3}\right)_{2}\right\} \mathrm{Y}\right]\right), 263$ (14, $\left.\left[\left\{\mathrm{C}_{8} \mathrm{H}_{6}\left(\mathrm{SiMe}_{3}\right)_{2}\right\} \mathrm{Y}-\mathrm{SiMe}_{3}\right]\right), 248\left(42,\left[\mathrm{C}_{8} \mathrm{H}_{6}\left(\mathrm{SiMe}_{3}\right)_{2}\right]\right), 207$ (66, $\left.\left[\mathrm{C}_{8} \mathrm{H}_{6}\left(\mathrm{SiMe}_{3}\right)_{2}-3 \mathrm{Me}\right]\right)$.

[Li(DME) $\left.)_{3}\right]\left[\mathbf{L a}\left\{\mathrm{C}_{8} \mathrm{H}_{6}\left(\mathrm{SiMe}_{3}\right)_{2}\right\}_{2}\right]$ (2). Yield: $3.34 \mathrm{~g}(61 \%)$, dec. $104{ }^{\circ} \mathrm{C}$. Elemental analysis calcd. for $\mathrm{C}_{40} \mathrm{H}_{78} \mathrm{LaLiO}_{6} \mathrm{Si}_{4}\left(M_{\mathrm{r}}=\right.$ $913.25 \mathrm{~g} \mathrm{~mol}^{-1}$ ): C, $52.61 ; \mathrm{H}, 8.61$. Found: C, $52.70 ; \mathrm{H}, 8.10 \%$. IR (KBr disc): $\nu=3436 \mathrm{w}, 3223 \mathrm{w}, 3090 \mathrm{w}, 2995 \mathrm{~m}, 2954 \mathrm{~s}, 2897 \mathrm{~m}$, $2830 \mathrm{w}, 2537 \mathrm{vw}, 2363 \mathrm{vw}, 2100 \mathrm{vw}, 1959 \mathrm{vw}, 1868 \mathrm{vw}, 1757 \mathrm{vw}$, $1638 \mathrm{w}, 1599 \mathrm{w}, 1452 \mathrm{w}, 1405 \mathrm{w}, 1370 \mathrm{w}, 1312 \mathrm{w}, 1248 \mathrm{~s}, 1210 \mathrm{w}$, $1193 \mathrm{w}, 1181 \mathrm{w}, 1156 \mathrm{w}, 1124 \mathrm{w}, 1086 \mathrm{~m}, 1065 \mathrm{w}, 1052 \mathrm{~m}, 1028 \mathrm{w}$, 981w, 932w, 910w, 837vs, 783vs, 750m, 716m, 690w, 681w, $651 \mathrm{w}, 636 \mathrm{w}, 550 \mathrm{vw}, 514 \mathrm{vw}, 504 \mathrm{vw}, 478 \mathrm{vw}, 459 \mathrm{vw}, 423 \mathrm{vw} \mathrm{cm}{ }^{-1}$. ${ }^{1} \mathrm{H}$ NMR (400.1 MHz, $d_{8}$-toluene, $24{ }^{\circ} \mathrm{C}$ ): $\delta=2.31$ (s, 18H, DME), 1.94 (s, 12H, DME), 0.67 (s, 36H, Si( $\left.\left.\mathrm{CH}_{3}\right)_{3}\right), 6.51-6.44(\mathrm{~m}, 8 \mathrm{H}$, COT- $H$ ), 6.40-6.35 (m, 4H, COT-H) ppm. ${ }^{13} \mathrm{C}$ NMR $(100.6 \mathrm{MHz}$, $d_{8}$-toluene, $24{ }^{\circ} \mathrm{C}$ ): $\delta=103.6$ (COT), 102.6 (COT), 101.3 (COT), 100.3 (COT), 69.3 (DME), 57.5 (DME), $1.1\left(\mathrm{Si}\left(\mathrm{CH}_{3}\right)_{3}\right) \mathrm{ppm}$.
${ }^{29} \mathrm{Si} \mathrm{NMR}\left(79.5 \mathrm{MHz}, d_{8}\right.$-toluene, $\left.24{ }^{\circ} \mathrm{C}\right): \delta=0.5 \mathrm{ppm}$. MS (EI): $m / z 636\left(1 \%,\left[\left\{\mathrm{C}_{8} \mathrm{H}_{6}\left(\mathrm{SiMe}_{3}\right)_{2}\right\}_{2} \mathrm{La}\right]\right), 387\left(38,\left[\left\{\mathrm{C}_{8} \mathrm{H}_{6}\left(\mathrm{SiMe}_{3}\right)_{2}\right\} \mathrm{La}\right]\right)$, $248\left(28,\left[\mathrm{C}_{8} \mathrm{H}_{6}\left(\mathrm{SiMe}_{3}\right)_{2}\right]\right), 207\left(34,\left[\mathrm{C}_{8} \mathrm{H}_{6}\left(\mathrm{SiMe}_{3}\right)_{2}\right]-3 \mathrm{Me}\right)$.

[Li(DME) $\left.)_{3}\right]\left[\operatorname{Pr}\left\{\mathbf{C}_{8} \mathbf{H}_{6}\left(\mathrm{SiMe}_{3}\right)_{2}\right\}_{2}\right]$ (3). Yield: $4.12 \mathrm{~g} \mathrm{(75 \% ),} \mathrm{dec.}$ $98{ }^{\circ} \mathrm{C}$. Elemental analysis calcd. for $\mathrm{C}_{40} \mathrm{H}_{78} \mathrm{LiO}_{6} \mathrm{PrSi}_{4}\left(M_{\mathrm{r}}=\right.$ $915.25 \mathrm{~g} \mathrm{~mol}^{-1}$ ): C, 52.49; H, 8.59. Found: C, 51.49; H, 8.31\%. IR (KBr disc): $\nu=3437 \mathrm{~m}, 3222 \mathrm{~m}, 3091 \mathrm{~m}, 3036 \mathrm{~m}, 2960 \mathrm{~s}, 2933 \mathrm{~m}$, 2535w, 2224vw, 2029vw, 1972vw, 1959w, 1743vw, 1637s, 1447m, $1419 \mathrm{~m}, 1383 \mathrm{~m}, 1371 \mathrm{~m}, 1343 \mathrm{~m}, 1308 \mathrm{~s}, 1245 \mathrm{vs}, 1181 \mathrm{~s}, 1157 \mathrm{vs}$, $1081 \mathrm{~m}, 1050 \mathrm{~m}, 985 \mathrm{~m}, 933 \mathrm{w}, 909 \mathrm{vw}, 837 \mathrm{~s}, 745 \mathrm{~m}, 733 \mathrm{w}, 698 \mathrm{w}$, $637 \mathrm{w}, 588 \mathrm{vw}, 555 \mathrm{w}, 504 \mathrm{~m}, 467 \mathrm{vw}, 458 \mathrm{vw}, 451 \mathrm{vw} \mathrm{cm}{ }^{-1} .{ }^{1} \mathrm{H} \mathrm{NMR}$ (400.1 MHz, $d_{8}$-THF, $\left.25{ }^{\circ} \mathrm{C}\right): \delta=3.63(12 \mathrm{H}, \mathrm{DME}), 3.31(18 \mathrm{H}$, DME), -6.17 (s, 27H, Si $\left.\left(\mathrm{CH}_{3}\right)_{3}\right),-13.52,-9.54,-0.05$ (br, s, COT- $H$ ) ppm. ${ }^{13} \mathrm{C}$ NMR $\left(100.6 \mathrm{MHz}, d_{8}\right.$-THF, $\left.25{ }^{\circ} \mathrm{C}\right): \delta=229.5$ (COT), 216.6 (СОT), 204.9 (COT), 192.7 (COT), 72.8 (DME), 59.0 (DME), $0.6\left(\mathrm{Si}\left(\mathrm{CH}_{3}\right)_{3}\right) \mathrm{ppm} .{ }^{29} \mathrm{Si} \mathrm{NMR}\left(79.5 \mathrm{MHz}, d_{8}-\mathrm{THF}, 25^{\circ} \mathrm{C}\right)$ : $\delta=-46 \mathrm{ppm}$. MS (EI): $m / z 637\left(4 \%,\left[\left\{\mathrm{C}_{8} \mathrm{H}_{6}\left(\mathrm{SiMe}_{3}\right)_{2}\right\}_{2} \mathrm{Pr}\right]\right), 389$ (100, [\{ $\left.\left.\left\{\mathrm{C}_{8} \mathrm{H}_{6}\left(\mathrm{SiMe}_{3}\right)_{2}\right\} \mathrm{Pr}\right]\right), 315\left(10,\left[\left\{\mathrm{C}_{8} \mathrm{H}_{6}\left(\mathrm{SiMe}_{3}\right)_{2}\right\} \mathrm{Pr}-\mathrm{SiMe}_{3}\right]\right)$, $248\left(22,\left[\mathrm{C}_{8} \mathrm{H}_{6}\left(\mathrm{SiMe}_{3}\right)_{2}\right]\right), 207\left(26,\left[\mathrm{C}_{8} \mathrm{H}_{6}\left(\mathrm{SiMe}_{3}\right)_{2}\right]-3 \mathrm{Me}\right)$.

[Li(DME) $\left.)_{3}\right]\left[\mathbf{G d}\left\{\mathbf{C}_{8} \mathbf{H}_{6}\left(\mathbf{S i M e}_{3}\right)_{2}\right\}_{2}\right]$ (4). Yield: $4.08 \mathrm{~g}$ (73\%), dec. $128{ }^{\circ} \mathrm{C}$. Elemental analysis calcd. for $\mathrm{C}_{40} \mathrm{H}_{78} \mathrm{GdLiO}_{6} \mathrm{Si}_{4}\left(M_{\mathrm{r}}=\right.$ 931.59 $\mathrm{g} \mathrm{mol}^{-1}$ ): C, 51.57; H, 8.44. Found: C, 50.83; H, 8.59\%. IR (KBr disc): $\nu=3788 \mathrm{vw}, 3546 \mathrm{w}, 3220 \mathrm{w}, 2997 \mathrm{~m}, 2953 \mathrm{~s}, 2897 \mathrm{~m}$, $2829 \mathrm{~m}, 2540 \mathrm{vw}, 2101 \mathrm{vw}, 1959 \mathrm{vw}, 1871 \mathrm{vw}, 1800 \mathrm{vw}, 1753 \mathrm{vw}$, $1637 \mathrm{w}, 1599 \mathrm{w}, 1543 \mathrm{w}, 1474 \mathrm{w}, 1451 \mathrm{~m}, 1404 \mathrm{w}, 1369 \mathrm{w}, 1310 \mathrm{w}$, $1248 \mathrm{~s}, 1210 \mathrm{w}, 1192 \mathrm{w}, 1124 \mathrm{~m}, 1086 \mathrm{~m}, 1066 \mathrm{~m}, 1053 \mathrm{~m}$, 1028w, 982w, 933m, 909w, 837vs, 782w, 769w, 750m, 717m, $680 \mathrm{w}, 651 \mathrm{w}, 636 \mathrm{w}, 548 \mathrm{w}, 521 \mathrm{vw}, 510 \mathrm{w}, 478 \mathrm{vw}, 459 \mathrm{vw}$, $421 \mathrm{vw} \mathrm{cm} \mathrm{cm}^{-1}$. NMR data could not be obtained for [Li(DME $\left.)_{3}\right]-$ $\left.\left[\mathrm{Gd}_{\{} \mathrm{C}_{8} \mathrm{H}_{6}\left(\mathrm{SiMe}_{3}\right)_{2}\right\}_{2}\right]$ due to the paramagnetic character of the $\mathrm{Gd}^{3+}$-ion. MS (EI): $\mathrm{m} / z 655\left(6 \%,\left[\left\{\mathrm{C}_{8} \mathrm{H}_{6}\left(\mathrm{SiMe}_{3}\right)_{2}\right\}_{2} \mathrm{Gd}\right]\right), 580$ (1, [\{ $\left.\left.\left\{\mathrm{C}_{8} \mathrm{H}_{6}\left(\mathrm{SiMe}_{3}\right)_{2}\right\}_{2} \mathrm{Gd}-\mathrm{SiMe}_{3}\right]\right), 406$ (14, [ $\left.\left.\left\{\mathrm{C}_{8} \mathrm{H}_{6}\left(\mathrm{SiMe}_{3}\right)_{2}\right\} \mathrm{Gd}\right]\right)$, $335\left(9,\left[\left\{\mathrm{C}_{8} \mathrm{H}_{6}\left(\mathrm{SiMe}_{3}\right)_{2}\right\} \mathrm{Gd}-\mathrm{SiMe}_{3}\right]\right), 248\left(54,\left[\mathrm{C}_{8} \mathrm{H}_{6}\left(\mathrm{SiMe}_{3}\right)_{2}\right]\right)$, $207\left(32,\left[\mathrm{C}_{8} \mathrm{H}_{6}\left(\mathrm{SiMe}_{3}\right)_{2}-3 \mathrm{Me}\right]\right)$.

$\left[\mathbf{L i}(\mathrm{THF})_{4}\right]\left[\mathrm{Ho}\left\{\mathrm{C}_{8} \mathrm{H}_{6}\left(\mathrm{SiMe}_{3}\right)_{2}\right\}_{2}\right]$ (5). Yield: $3.30 \mathrm{~g}(57 \%)$, dec. $113{ }^{\circ} \mathrm{C}$. Elemental analysis calcd. for $\mathrm{C}_{44} \mathrm{H}_{80} \mathrm{LiO}_{4} \mathrm{Si}_{4} \mathrm{Ho}\left(M_{\mathrm{r}}=\right.$ $957.33 \mathrm{~g} \mathrm{~mol}^{-1}$ ): C, 55.20; H, 8.42. Found: C, 54.93; H, 8.29\%. IR (KBr disc): $\nu=3036 \mathrm{w}, 2953 \mathrm{vs}, 2896 \mathrm{~s}, 2833 \mathrm{~m}, 2088 \mathrm{vw}, 1932 \mathrm{vw}$, $1876 \mathrm{vw}, 1834 \mathrm{vw}, 1779 \mathrm{vw}, 1667 \mathrm{vw}, 1590 \mathrm{w}, 1536 \mathrm{w}, 1487 \mathrm{w}$, $1446 \mathrm{~m}, 1403 \mathrm{~m}, 1317 \mathrm{w}, 1247 \mathrm{vs}, 1214 \mathrm{~m}, 1049 \mathrm{~s}, 1038 \mathrm{~m}, 982 \mathrm{~m}$, 939s, 910m, 894m, 839vs, 783m, 748s, 735vs, 686m, 651w, 636s，573vw，550m，540w，522vw，512w，488vw，463vw， $423 \mathrm{vw} \mathrm{cm}{ }^{-1}$. NMR data could not be obtained for [Li(THF $\left.)_{4}\right]-$ $\left[\mathrm{Ho}\left\{\mathrm{C}_{8} \mathrm{H}_{6}\left(\mathrm{SiMe}_{3}\right)_{2}\right\}_{2}\right]$ due to the paramagnetic character of the $\mathrm{Ho}^{3+}$-ion. MS (EI): $\mathrm{m} / z$ $662\left(5 \%,\left[\left\{\mathrm{C}_{8} \mathrm{H}_{6}\left(\mathrm{SiMe}_{3}\right)_{2}\right\}_{2} \mathrm{Ho}\right]\right), 589$ (5, $\left.\left.\left[\mathrm{C}_{8} \mathrm{H}_{6}\left(\mathrm{SiMe}_{3}\right)_{2}\right\}_{2} \mathrm{Ho} \mathrm{SiMe}_{3}\right]\right), 412\left(5,\left[\mathrm{C}_{8} \mathrm{H}_{6}\left(\mathrm{SiMe}_{3}\right)_{2} \mathrm{Ho}\right]\right), 340$ $\left(30,\left[\mathrm{C}_{8} \mathrm{H}_{6}\left(\mathrm{SiMe}_{3}\right)_{2} \mathrm{Ho}-\mathrm{SiMe}_{3}\right]\right), 248\left(40,\left[\mathrm{C}_{8} \mathrm{H}_{6}\left(\mathrm{SiMe}_{3}\right)_{2}\right]\right), 206$ $\left(100,\left[\mathrm{C}_{8} \mathrm{H}_{6}\left(\mathrm{SiMe}_{3}\right)_{2}-3 \mathrm{Me}\right]\right)$.

[Li(DME) $\left.)_{3}\right]\left[\mathbf{T m}\left\{\mathrm{C}_{8} \mathbf{H}_{6}\left(\mathrm{SiMe}_{3}\right)_{2}\right\}_{2}\right]$ (6). Yield: $3.79 \mathrm{~g}(67 \%)$, dec. $125{ }^{\circ} \mathrm{C}$. Elemental analysis calcd. for $\mathrm{C}_{40} \mathrm{H}_{78} \mathrm{LiO}_{6} \mathrm{Si}_{4} \mathrm{Tm}\left(M_{\mathrm{r}}=\right.$ $943.27 \mathrm{~g} \mathrm{~mol}^{-1}$ ): C, 50.93; H, 8.33. Found: C, 50.50; H, 7.95\%. IR (KBr disc): $\nu=3469 \mathrm{w}, 3222 \mathrm{w}, 2994 \mathrm{~m}, 2956 \mathrm{~s}, 2898 \mathrm{~m}, 2535 \mathrm{vw}$, $1959 \mathrm{vw}, 1637 \mathrm{~m}, 1450 \mathrm{w}, 1406 \mathrm{w}, 1385 \mathrm{w}, 1314 \mathrm{w}, 1248 \mathrm{~s}, 1212 \mathrm{w}$, 1181w, 1152w, 1125w, 1081w, 1052w, 1028w, 982w, 934w, 837vs $750 \mathrm{~m}, 736 \mathrm{w}, 719 \mathrm{~m}, 691 \mathrm{w}, 651 \mathrm{w}, 634 \mathrm{w}, 547 \mathrm{vw}, 519 \mathrm{vw}, 505 \mathrm{vw}$, $479 \mathrm{vw}, 463 \mathrm{vw} \mathrm{cm}^{-1}$. NMR data could not be obtained for 
$\left[\mathrm{Li}(\mathrm{DME})_{3}\right]\left[\mathrm{Tm}\left\{\mathrm{C}_{8} \mathrm{H}_{6}\left(\mathrm{SiMe}_{3}\right)_{2}\right\}_{2}\right]$ due to the paramagnetic character of the $\mathrm{Tm}^{3+}$-ion.

[Li(THF $\left.)_{4}\right]\left[\mathbf{T m}\left\{\mathrm{C}_{8} \mathrm{H}_{6}\left(\mathrm{SiMe}_{3}\right)_{2}\right\}_{2}\right]$ (7). Yield: $3.17 \mathrm{~g}(55 \%)$, dec. $133{ }^{\circ} \mathrm{C}$. Elemental analysis calcd. for $\mathrm{C}_{44} \mathrm{H}_{80} \mathrm{LiO}_{4} \mathrm{Si}_{4} \mathrm{Tm}\left(M_{\mathrm{r}}=\right.$ $961.33 \mathrm{~g} \mathrm{~mol}^{-1}$ ): C, $54.97 ; \mathrm{H}, 8.39$. Found: C, $54.15 ; \mathrm{H}, 7.80 \%$. IR (KBr disc): $\nu=3469 \mathrm{vw}, 3030 \mathrm{~m}, 2996 \mathrm{~m}, 2952 \mathrm{~s}, 2897 \mathrm{~m}, 2830 \mathrm{~m}$, $2543 \mathrm{vw}, 2349 \mathrm{vw}, 2271 \mathrm{vw}, 2102 \mathrm{vw}, 1959 \mathrm{vw}, 1872 \mathrm{vw}, 1803 \mathrm{vw}$, $1754 \mathrm{vw}, 1636 \mathrm{w}, 1599 \mathrm{w}, 1549 \mathrm{w}, 1475 \mathrm{ww}, 1451 \mathrm{~m}, 1404 \mathrm{w}, 1369 \mathrm{w}$, $1328 \mathrm{w}, 1311 \mathrm{w}, 1247 \mathrm{~s}, 1214 \mathrm{w}, 1192 \mathrm{w}, 1158 \mathrm{w}, 1124 \mathrm{~m}, 1087 \mathrm{~s}$, 1053m, 1028w, 983w, 934m, 911w, 836vs, 783w, 771w, 750m, 719s, 680w, 651w, 636m, 573vw, 547w, 518vw, 507w, 479vw, $457 \mathrm{vw}, 423 \mathrm{vw} \mathrm{cm}^{-1}$. NMR data could not be obtained for $\left[\mathrm{Li}(\mathrm{DME})_{3}\right]\left[\mathrm{Tm}\left\{\mathrm{C}_{8} \mathrm{H}_{6}\left(\mathrm{SiMe}_{3}\right)_{2}\right\}_{2}\right]$ due to the paramagnetic character of the $\mathrm{Tm}^{3+}$-ion. MS (EI): $\mathrm{m} / z 665\left(8 \%,\left[\left\{\mathrm{C}_{8} \mathrm{H}_{6}\left(\mathrm{SiMe}_{3}\right)_{2}\right\}_{2} \mathrm{Tm}\right]\right)$, $593\left(2,\left[\left\{\mathrm{C}_{8} \mathrm{H}_{6}\left(\mathrm{SiMe}_{3}\right)_{2}\right\}_{2} \mathrm{Tm}-\mathrm{SiMe}_{3}\right]\right), 417\left(22,\left[\left\{\mathrm{C}_{8} \mathrm{H}_{6}\left(\mathrm{SiMe}_{3}\right)_{2}\right\} \mathrm{Tm}\right]\right)$, $343\left(3,\left[\left\{\mathrm{C}_{8} \mathrm{H}_{6}\left(\mathrm{SiMe}_{3}\right)_{2}\right\} \mathrm{Tm}-\mathrm{SiMe}_{3}\right]\right), 248\left(48,\left[\mathrm{C}_{8} \mathrm{H}_{6}\left(\mathrm{SiMe}_{3}\right)_{2}\right]\right)$, $207\left(66,\left[\mathrm{C}_{8} \mathrm{H}_{6}\left(\mathrm{SiMe}_{3}\right)_{2}-3 \mathrm{Me}\right]\right)$.

[Li(DME) $\left.)_{3}\right]\left[\mathbf{L u}\left\{\mathbf{C}_{8} \mathbf{H}_{6}\left(\mathrm{SiMe}_{3}\right)_{2}\right\}_{2}\right]$ (8). Yield: $4.21 \mathrm{~g}(74 \%)$, dec. ca. $90{ }^{\circ} \mathrm{C}$. Elemental analysis calcd. for $\mathrm{C}_{40} \mathrm{H}_{78} \mathrm{LiLuO}_{6} \mathrm{Si}_{4}\left(M_{\mathrm{r}}=\right.$ 949.31 $\mathrm{g} \mathrm{mol}^{-1}$ ): C, 50.61; H, 8.28. Found: C, 49.47; H, 8.20\%. IR (KBr disc): $\nu=3437 \mathrm{w}, 3222 \mathrm{w}, 2994 \mathrm{~m}, 2956 \mathrm{~s}, 2897 \mathrm{~m}, 2536 \mathrm{vw}$, $2354 \mathrm{vw}, 2096 \mathrm{vw}, 1959 \mathrm{vw}, 1868 \mathrm{vw}, 1635 \mathrm{w}, 1599 \mathrm{~m}, 1452 \mathrm{w}$, $1406 \mathrm{w}, 1385 \mathrm{w}, 1317 \mathrm{w}, 1248 \mathrm{~s}, 1206 \mathrm{w}, 1181 \mathrm{w}, 1113 \mathrm{w}, 1097 \mathrm{w}$, $1065 \mathrm{w}, 1044 \mathrm{w}, 1028 \mathrm{w}, 983 \mathrm{w}, 940 \mathrm{w}, 837 \mathrm{vs}, 810 \mathrm{~m}, 750 \mathrm{~m}, 738 \mathrm{w}$, $720 \mathrm{~m}, 692 \mathrm{w}, 674 \mathrm{w}, 651 \mathrm{w}, 624 \mathrm{w}, 556 \mathrm{vw}, 503 \mathrm{vw}, 478 \mathrm{vw}, 459 \mathrm{w}$, $437 \mathrm{vw}, 422 \mathrm{vw} \mathrm{cm}{ }^{-1} .{ }^{1} \mathrm{H}$ NMR $\left(400.1 \mathrm{MHz}, d_{8}\right.$-THF, $\left.25{ }^{\circ} \mathrm{C}\right): \delta=$ 3.39 (s, 12H, DME), 3.25 (s, 18H, DME), 0.43 (s, 36H, Si( $\left.\mathrm{CH}_{3}\right)_{3}$ ), 6.06-6.03 (m, 8H, COT- $H$ ), 5.85-5.82 (m, 4H, COT- $H$ ) ppm. ${ }^{13} \mathrm{C}$ NMR $\left(100.6 \mathrm{MHz}, d_{8}\right.$-THF, $\left.25{ }^{\circ} \mathrm{C}\right): \delta=98.1$ (COT), 97.9 (COT),

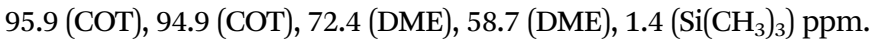
${ }^{29} \mathrm{Si}$ NMR (79.5 MHz, $d_{8}$-THF, $\left.25{ }^{\circ} \mathrm{C}\right): \delta=0.8 \mathrm{ppm}$. MS (EI): $\mathrm{m} / z 672$ $\left(71 \%,\left[\left\{\mathrm{C}_{8} \mathrm{H}_{6}\left(\mathrm{SiMe}_{3}\right)_{2}\right\}_{2} \mathrm{Lu}+\mathrm{H}\right]\right), 423\left(64,\left[\left\{\mathrm{C}_{8} \mathrm{H}_{6}\left(\mathrm{SiMe}_{3}\right)_{2}\right\} \mathrm{Lu}\right]\right), 248$ (64, $\left.\left[\mathrm{C}_{8} \mathrm{H}_{6}\left(\mathrm{SiMe}_{3}\right)_{2}\right]\right), 207\left(34,\left[\mathrm{C}_{8} \mathrm{H}_{6}\left(\mathrm{SiMe}_{3}\right)_{2}-3 \mathrm{Me}\right]\right)$.

\subsection{Preparation of the actinide sandwich complexes} $\operatorname{An}\left(\mathrm{COT}^{\prime \prime}\right)_{2}(\mathrm{An}=\mathrm{Th}(9), \mathrm{U}(10))$ (general synthetic protocol)

$\sim 200 \mathrm{mg}$ of anhydrous $\mathrm{AnCl}_{4}(\mathrm{An}=\mathrm{Th}, \mathrm{U} ; \sim 0.5 \mathrm{mmol})$ were treated with 2.05 equiv. of freshly prepared $\mathrm{Li}_{2}\left(\mathrm{COT}^{\prime \prime}\right)$ in $25 \mathrm{~mL}$ of THF. Due to the high solubility of all reactants the reactions were finished after $2 \mathrm{~h}$ stirring at r.t. The solvent was evaporated and $n$-pentane $(20 \mathrm{~mL})$ was added, yielding an intense yellow solution (Th) and a red-green solution for the U complex 10. Filtration and removal of the solvents afforded the crude complexes in $\sim 80 \%$ yield. From the waxy yellow thorium complex 9 (m.p. $135{ }^{\circ} \mathrm{C}$ ) single-crystals were obtained by recrystallization in a closed ampule at $240{ }^{\circ} \mathrm{C}$ under high vacuum. From the oily, crude uranium complex 10, single-crystals grew in the refrigerator during storage at $4{ }^{\circ} \mathrm{C}$ for several months. Sublimation under identical conditions as described for Th led to the formation of red crystals in a green oil.

$\mathrm{Th}\left[\mathrm{C}_{8} \mathrm{H}_{6}\left(\mathrm{SiMe}_{3}\right)_{2}\right]_{2}$ (9). Elemental analysis calcd. for $\mathrm{C}_{28} \mathrm{H}_{48} \mathrm{Si}_{4} \mathrm{Th}\left(M_{\mathrm{r}}=729.07 \mathrm{~g} \mathrm{~mol}^{-1}\right): \mathrm{C}, 46.13 ; \mathrm{H}, 6.64 ; \mathrm{Th}$, 31.83. Found: Th, $32.0 \%$. IR ( $\mathrm{KBr}$ disc): $\nu=3036 \mathrm{w}, 3002 \mathrm{~m}$, $2954 \mathrm{~m}, 2895 \mathrm{~m}, 1447 \mathrm{w}, 1403 \mathrm{w}, 1382 \mathrm{w}, 1370 \mathrm{w}, 1330 \mathrm{w}, 1302 \mathrm{w}$, 1249s, 1119w, 1051w, 1042w, 1018m, 988m, 964m, 926m, 838vs br, $812 \mathrm{~m}, 806 \mathrm{~m}, 780 \mathrm{w}, 750 \mathrm{~s}, 720 \mathrm{~s}, 710 \mathrm{~m}, \mathrm{sh}, 699 \mathrm{w}, 661 \mathrm{w}, 633 \mathrm{~m}$,
$470 \mathrm{w}, 347 \mathrm{~m}, 302 \mathrm{~m}, 241 \mathrm{~m} \mathrm{~cm}^{-1} \cdot{ }^{1} \mathrm{H}$ NMR $\left(\mathrm{CDCl}_{3}\right): \delta=6.86$ $(\mathrm{m}, 12 \mathrm{H}, \mathrm{CH}), 0.60\left(\mathrm{br}, 36 \mathrm{H}, \mathrm{CH}_{3}\right) \mathrm{ppm} .{ }^{13} \mathrm{C} \mathrm{NMR}\left(\mathrm{CDCl}_{3}\right): \delta=$ 113.1, 112.3, $110.0(\mathrm{CH}), 0.9\left(\mathrm{CH}_{3}\right) \mathrm{ppm}$.

$\mathrm{U}\left[\mathrm{C}_{8} \mathrm{H}_{6}\left(\mathrm{SiMe}_{3}\right)_{2}\right]_{2}$ (10). Elemental analysis calcd. for $\mathrm{C}_{28} \mathrm{H}_{48} \mathrm{Si}_{4} \mathrm{U}\left(M_{\mathrm{r}}=735.06 \mathrm{~g} \mathrm{~mol}^{-1}\right): \mathrm{C}, 45.75 ; \mathrm{H}, 6.58 ; \mathrm{U}, 32.38$. Found: U, 31.9\%. IR (KBr disc): $\nu=3031 \mathrm{w}, 2999 \mathrm{~m}, 2956 \mathrm{~m}$, 2896m, 1586w, 1445w, 1403w, 1247s, 1081w, 1066w, 1038s, $977 \mathrm{~m}, 940 \mathrm{~m}, 931 \mathrm{~m}, 900 \mathrm{~m}, 838 \mathrm{vs}$, br, 793w, 750s, 742m, $710 \mathrm{~m}, \mathrm{sh}, 691 \mathrm{w}, 651 \mathrm{w}, 633 \mathrm{~m}, 540 \mathrm{w}, 502 \mathrm{w}, 478 \mathrm{w}, 458 \mathrm{w}$, $422 \mathrm{w}, 338 \mathrm{~m}, 303 \mathrm{~m}, 283 \mathrm{w}, 249 \mathrm{~m} \mathrm{~cm} \mathrm{~cm}^{-1}$. UV-vis $\left(\mathrm{Et}_{2} \mathrm{O}, \lambda, \mathrm{nm}\right.$ $\left.\left(\varepsilon, \mathrm{cm} \mathrm{l} \mathrm{mol}^{-1}\right)\right): 360,380,503,520,537,567,592(1461), 618(438)$, 635(195), 691(20), 732(19), 980(17), 1322(4), 1479(7), 1710(1), 1755(1), 1793(1), 1865(6) nm. ${ }^{1} \mathrm{H}$ NMR $\left(\mathrm{CDCl}_{3}\right): \delta=-9.99(36 \mathrm{H}$, $\left.\mathrm{CH}_{3}\right),-25.20(4 \mathrm{H}, \mathrm{CH}),-39.63(4 \mathrm{H}, \mathrm{CH}),-45.62(4 \mathrm{H}, \mathrm{CH}) \mathrm{ppm}$. ${ }^{13} \mathrm{C}$ NMR $\left(\mathrm{CDCl}_{3}\right): \delta=325.9(\mathrm{CH}), 293.8(\mathrm{CH}), 270.3(\mathrm{CH})$, $-3.5\left(\mathrm{CH}_{3}\right) \mathrm{ppm}$.

\subsection{Preparation of the actinide sandwich complexes $\operatorname{An}\left(\mathrm{COT}^{\prime \prime \prime}\right)_{2}(\mathrm{An}=\mathrm{Th}(11), \mathrm{U}(12))$}

The two polysilylated actinidocenes $\mathbf{1 1}$ and $\mathbf{1 2}$ were prepared by treatment of $\mathrm{AnCl}_{4}(\mathrm{An}=\mathrm{Th}, \mathrm{U})$ with 2 equiv. of $\mathrm{K}_{2}\left(\mathrm{COT}^{\prime \prime \prime}\right)$, following the procedure reported by Edelmann and Kanellakopulos et al. (cf. Scheme 5). ${ }^{24 b}$ Bright yellow 11 and dichroitic red/green 12 were isolated in high yields of around $80 \%$ after recrystallization from $n$-pentane.

\subsection{Crystal structure determination}

The intensity data of the lanthanide sandwich complexes 1-8 were collected on a Stoe IPDS $2 \mathrm{~T}$ diffractometer with MoK $\alpha$ radiation. The data were collected with the Stoe XAREA program using $\omega$-scans. ${ }^{39}$ The space groups were determined with the XRED32 program. The structures were solved by direct methods (SHELXS-97) and refined by full matrix leastsquares methods on $F^{2}$ using SHELXL-97. ${ }^{40}$ Data collection parameters are summarized in Tables 1 and 2. Single-crystal X-ray analyses of the actinide complexes 9-12 were performed on a Bruker Apex II Quazar diffractometer at given temperature, collecting two or four spheres of data with an irradiation time of 10 to $40 \mathrm{~s}$ per frame, applying a combination of $\omega$ - and $\varphi$-scans. Maximum $\theta$-values were in the range of $28^{\circ}$. Completeness of data to $\theta \leq 25^{\circ}$ was higher than $99 \%$. For more information refer to Table 2. Integration of the data proceeded with SAINT, ${ }^{41}$ the data were corrected for Lorentzand polarisation effects, and an experimental absorption correction with SADABS ${ }^{41}$ was performed. For searches relating to single-crystal X-ray diffraction data, the Cambridge Structural Database was used. The structures have been solved by direct methods and refined to a minimum $R$-value with SHELXL-2013 ${ }^{42}$ via full-matrix least-squares on $F^{2}$. In the case of compound 9, a second type of crystals could be isolated with a different elementary cell showing a strong disorder. The data have been deposited at the CCDC with the CCDC 1049928 but will not be discussed here in detail as due to the disorder the overall standard deviations for all values are significantly higher. 


\section{Acknowledgements}

Financial support by the Otto-von-Guericke-Universität Magdeburg is gratefully acknowledged. Special thanks are due to Ms Desirée Schneider for preparing the ChemDraw Schemes.

\section{References}

1 Review: F. T. Edelmann, Complexes of Scandium, Yttrium and Lanthanide Elements, in Comprehensive Organometallic Chemistry III, ed. R. H. Crabtree and D. M. P. Mingos, Elsevier, Oxford, 2006, p. 1.

2 C. Meermann, K. Ohno, K. W. Törnroos, K. Mashima and R. Anwander, Eur. J. Inorg. Chem., 2009, 76, and references cited therein.

3 (a) F. Mares, K. O. Hodgson and A. Streitwieser, J. Organomet. Chem., 1970, 24, C68; (b) K. O. Hodgson, F. Mares, D. Starks and A. Streitwieser, J. Am. Chem. Soc., 1973, 85, 8650; (c) S. A. Kinsley, A. Streitwieser and A. Zalkin, Organometallics, 1985, 4, 52; (d) A. L. Wayda, Organometallics, 1983, 2, 565; (e) J. Jin, Z. Jin, G. Wei, W. Chen and Y. Zhang, Chin. J. Inorg. Chem., 1993, 9, 326; $(f)$ U. Kilimann, M. Schäfer, R. Herbst-Irmer and F. T. Edelmann, J. Organomet. Chem., 1994, 469, C15; (g) S. Anfang, G. Seybert, K. Harms, G. Geiseler, W. Massa and K. Dehnicke, Z. Anorg. Allg. Chem., 1998, 624, 1187; (h) G. W. Rabe, M. Zhang-Presse, J. A. Golen and A. L. Rheingold, Acta Crystallogr., Sect. E: Struct. Rep. Online, 2003, 59, m255.

4 (a) F. Mares, K. O. Hodgson and A. Streitwieser, J. Organomet. Chem., 1971, 28, C24; (b) K. O. Hodgson and K. N. Raymond, Inorg. Chem., 1972, 11, 171; (c) K. O. Hodgson and K. N. Raymond, Inorg. Chem., 1972, 11, 3030; (d) A. L. Wayda, Organometallics, 1983, 2, 565; (e) J. Xia, Z. Jin, G. Wei and W. Chen, Jiegou Huaxue, 1992, $11,113$.

5 (a) J. D. Jamerson, A. P. Masino and J. Takats, J. Organomet. Chem., 1974, 65, C33; (b) A. Westerhoff and H. J. De LiefdeMeijer, J. Organomet. Chem., 1976, 116, 319; (c) K. Wen, Z. Jin and W. Chen, J. Chem. Soc., Chem. Commun., 1991, 680.

6 A. Greco, S. Cesca and G. Bertolini, J. Organomet. Chem., 1976, 113, 321.

7 (a) A. Streitwieser and S. A. Kinsley, in Fundamental and Technological Aspects of Organo-f-Element Chemistry, ed. T. J. Marks and I. L. Fragalà, NATO ASI Series, D. Reidel, Boston, 1985, vol. 155, p. 77; (b) A. Streitwieser and T. R. Boussie, Eur. J. Solid State Inorg. Chem., 1991, 28, 399; (c) F. T. Edelmann, New J. Chem., 1995, 19, 535; (d) F. T. Edelmann, Angew. Chem., Int. Ed., 1995, 34, 2466; (e) F. T. Edelmann, D. M. M. Freckmann and H. Schumann, Chem. Rev., 2002, 102, 1851; $(f)$ H.-D. Amberger, F. T. Edelmann, J. Gottfriedsen, R. Herbst-Irmer, S. Jank, U. Kilimann, M. Noltemeyer, H. Reddmann and M. Schäfer, Inorg. Chem., 2009, 48, 760; $(g)$ F. T. Edelmann, New J. Chem., 2011, 35, 517.
8 K. Mashima and H. Takaya, Tetrahedron Lett., 1989, 30, 3697.

9 (a) U. Kilimann, M. Schäfer, R. Herbst-Irmer and F. T. Edelmann, J. Organomet. Chem., 1994, 469, C10; (b) H. Schumann, J. Winterfeld, H. Hemling, F. E. Hahn, P. Reich, K.-W. Brzezinka, F. T. Edelmann, U. Kilimann, M. Schäfer and R. Herbst-Irmer, Chem. Ber., 1995, 128, 395; (c) U. Reißmann, P. Poremba, M. Noltemeyer, H.-G. Schmidt and F. T. Edelmann, Inorg. Chim. Acta, 2000, 303, 156.

10 (a) J. M. Bellama and J. B. Davidson, J. Organomet. Chem., 1975, 86, 69; (b) N. C. Burton, F. G. N. Cloke, P. B. Hitchcock, H. C. de Lemos and A. A. Sameh, J. Chem. Soc., Chem. Commun., 1989, 1462; (c) N. C. Burton, F. G. N. Cloke, S. C. P. Joseph, H. Karamallakis and A. A. Sameh, J. Organomet. Chem., 1993, 462, 39.

11 A. Streitwieser and U. Müller-Westerhoff, J. Am. Chem. Soc., 1968, 90, 7364.

12 Review: D. Seyferth, Organometallics, 2004, 23, 3562.

13 (a) A. Hervé, N. Garin, P. Thuéry, M. Ephritikhine and J.-C. Berthet, Chem. Commun., 2013, 49, 6304; (b) J.-C. Berthet, P. Thuéry, N. Garin, J.-P. Dognon, T. Cantat and M. Ephritikhine, J. Am. Chem. Soc., 2013, 135, 10003.

14 A. Edelmann, V. Lorenz, C. G. Hrib, L. Hilfert, S. Blaurock and F. T. Edelmann, Organometallics, 2013, 32, 1435.

15 V. Lorenz, A. Edelmann, S. Blaurock, F. Freise and F. T. Edelmann, Organometallics, 2007, 26, 4708.

16 V. Lorenz, S. Blaurock, C. G. Hrib and F. T. Edelmann, Organometallics, 2010, 29, 4787.

17 J. J. Le Roy, M. Jeletic, S. I. Gorelski, I. Korobkov, L. Ungur, L. F. Chibotaru and M. Murugesu, J. Am. Chem. Soc., 2013, $135,3502$.

18 J. J. Le Roy, L. Ungur, I. Korobkov, L. F. Chibotaru and M. Murugesu, J. Am. Chem. Soc., 2014, 136, 8003.

19 P. Poremba, U. Reißmann, M. Noltemeyer, H.-G. Schmidt, W. Brüser and F. T. Edelmann, J. Organomet. Chem., 1997, $544,1$.

20 J. J. Le Roy, I. Korobkov, J. E. Kim, E. J. Schelter and M. Murugesu, Dalton Trans., 2014, 43, 2737.

21 J. J. Le Roy, I. Korobkov and M. Murugesu, Chem. Commun., 2014, 50, 1602.

22 V. Lorenz, A. Edelmann, S. Blaurock, F. Freise and F. T. Edelmann, Organometallics, 2007, 26, 6681.

23 M. Jeletic, P.-H. Lin, J. J. Le Roy, I. Korobkov, S. I. Gorelsky and M. Murugesu, J. Am. Chem. Soc., 2011, 133, 19286.

24 (a) U. Kilimann, R. Herbst-Irmer, D. Stalke and F. T. Edelmann, Angew. Chem., Int. Ed., 1994, 33, 1618; (b) C. Apostolidis, F. T. Edelmann, B. Kanellakopulos and U. Reißmann, Z. Naturforsch., 1999, 54b, 960.

25 A. Edelmann, S. Blaurock, V. Lorenz, L. Hilfert and F. T. Edelmann, Angew. Chem., Int. Ed., 2007, 46, 6732.

26 A. Edelmann, C. G. Hrib, S. Blaurock and F. T. Edelmann, J. Organomet. Chem., 2010, 695, 2732.

27 J. J. Le Roy, S. I. Gorelsky, I. Korobkov and M. Murugesu, Organometallics, 2015, 34, 1415.

28 (a) P. Poremba, H. G. Schmidt, M. Noltemeyer and F. T. Edelmann, Organometallics, 1998, 17, 986; (b) M. Jeletic, 
F. A. Perras, S. I. Gorelsky, J. L. Le Roy, I. Korobkov, D. L. Bryce and M. Murugesu, Dalton Trans., 2012, 41, 8060.

29 (a) A. Avdeef, K. N. Raymond, K. O. Hodgson and A. Zalkin, Inorg. Chem., 1972, 11, 1083; (b) K. O. Hodgson and K. N. Raymond, Inorg. Chem., 1973, 12, 458; (c) L. K. Templeton, D. H. Templeton and R. Walker, Inorg. Chem., 1976, 15, 3000; (d) A. Zalkin, D. H. Templeton, S. R. Berryhill and W. D. Luke, Inorg. Chem., 1979, 18, 2287; (e) A. Zalkin, D. H. Templeton, W. D. Luke and A. Streitwieser Jr., Organometallics, 1982, 1, 618; $(f)$ A. Zalkin, D. H. Templeton, R. Kluttz and A. Streitwieser Jr., Acta Crystallogr., Sect. C: Cryst. Struct. Commun., 1985, 41, 327.

30 V. Lorenz, B. M. Schmiege, C. G. Hrib, J. W. Ziller, A. Edelmann, S. Blaurock, W. J. Evans and F. T. Edelmann, J. Am. Chem. Soc., 2011, 133, 1257.

31 (a) H. P. Fritz, Adv. Organomet. Chem., 1964, 1, 239; (b) L. Hocks, J. Goffart, G. Duyckaert and P. Teyssie, Spectrochim. Acta, Part A, 1974, 30, 907; (c) V. T. Aleksanyan, I. A. Garbusova, T. M. Chernyshova, Z. V. Todres, M. R. Leonov and N. I. Gramateeva, J. Organomet. Chem., 1981, 217, 169.

32 (a) A. Streitwieser and U. Müller-Westerhoff, J. Am. Chem. Soc., 1973, 95, 8644; (b) R. Bohlander, PhD thesis, University of Karlsruhe, 1986; (c) N. Magnani, C. Apostolidis, A. Morgenstern, E. Colineau, J.-C. Griveau, H. Bolvin, O. Walter and R. Caciuffo, Angew. Chem., Int. Ed., 2011, 50, 1696.

33 C. R. Graves, A. E. Vaughn, E. J. Schelter, B. L. Scott, J. D. Thompson, D. E. Morris and J. L. Kiplinger, Inorg. Chem., 2008, 47, 11879, and references cited therein.
34 (a) A. Streitwieser, Jr., R. Q. Kluttz, K. A. Smith and W. D. Luke, Organometallics, 1983, 2, 1873; (b) W. Jahn, K. Yünlü, W. Oroschin, H.-D. Amberger and R. D. Fischer, Inorg. Chim. Acta, 1984, 95, 85; (c) A. Streitwieser Jr., M. H. Lyttle, H.-K. Wang, T. Boussie, A. Weinländer and J. P. Solar, J. Organomet. Chem., 1995, 501, 245.

35 (a) A. W. Spiegl, Doctoral dissertation, University of Erlangen-Nürnberg, 1978; (b) R. D. Fischer, NMRspectroscopy of Organo-f-Element and Pre-Lanthanoid Complexes: Some Current Trends, in Fundamental and Technological Aspects of Organo-f-Element Chemistry, ed. T. J. Marks and I. L. Fragala and D. Reidel Publishing Company, 1985, pp. 277-326.

36 J. H. Freeman and M. L. Smith, J. Inorg. Nucl. Chem., 1958, $7,224$.

37 D. C. Bradley, M. A. Saad and W. wardlaw, J. Chem. Soc., 1954, 2002.

38 J. A. Hermann, J. F. Suttle and H. R. Hoekstra, Inorg. Synth., 1957, 5, 143.

39 Stoe, XAREA, Program for X-ray Crystal Data Collection, (XRED32 included in XAREA) Stoe, 2002.

40 (a) G. M. Sheldrick, SHELXL-97 Program for Crystal Structure Refinement, Universität Göttingen, Germany, 1997; (b) G. M. Sheldrick, SHELXS-97 Program for Crystal Structure Solution, Universität Göttingen, Germany, 1997.

41 Bruker APEX, SAINT, SADABS, programs for X-ray Crystal Data Collection, integration and absorption correction, Bruker AXS Inc., Madison, Wisconsin, USA, 2007.

42 G. M. Sheldrick, Acta Crystallogr., Sect. A: Found. Crystallogr., 2008, 64, 112. 